Article

\title{
Advancing Water Sustainability in Megacities: Comparative Study of São Paulo and Delhi Using a Social-Ecological System Framework
}

\author{
Rimjhim M. Aggarwal ${ }^{1, *}$ and LaDawn Haglund ${ }^{2}$ \\ 1 School of Sustainability, Arizona State University, Tempe, AZ 85287, USA \\ 2 Justice and Social Inquiry, Arizona State University, Tempe, AZ 85287, USA; ladawn.haglund@asu.edu \\ * Correspondence: rimjhim@asu.edu; Tel.: +1-480-965-6680
}

Received: 1 July 2019; Accepted: 17 September 2019; Published: 26 September 2019

check for updates

\begin{abstract}
In this paper, we frame the problem of urban water sustainability in megacities as a social-ecological system (SES) to examine the underlying coupling of social and ecological factors and processes. Based on our empirical research of two major megacities of the global south, São Paulo and Delhi, we have developed an urban water SES module within the broader SES framework proposed by Ostrom. The module's multilevel nested structure consists of the following four subsystems: water resource and infrastructure, settlements, governance, and actors. A distinct advantage of our module is that it enables us to capture the plurality of settlements patterns (from formal to informal settlements), actor networks, and governance patterns found in cities of the global south and how these uniquely shape and are shaped by the process of rapid urbanization. We use this module as: (a) an analytical tool to identify the different variables and processes within each subsystem, which through their interactions, have influenced the trajectory of water systems in these cities; (b) a diagnostic tool in a comparative setting to examine why desired goals in terms of service delivery and/or governance were achieved (or not); and (c) a prescriptive tool to identify cross-learnings and practical lessons.
\end{abstract}

Keywords: urban sustainability; water governance; social-ecological systems; global south; informality; São Paulo; Delhi

\section{Introduction}

Recent cases of water crises in major metropolitan regions of the global south-such as Chennai, Cape Town, and São Paulo-have drawn worldwide attention by raising the specter of taps running dry [1,2]. Scientific evidence has been mounting that the extreme climate events that triggered these crises can no longer be treated as rare [3], which calls for fundamentally different approaches to sustainable urban management. However, we find that the dominant narrative on these crises continues to call for more control and predictability through investments in increasing supply from more distant and/or deeper sources [4]. This continues the pattern of unsustainability by limiting the set of potential solutions and is grossly inadequate in terms of our search for transformative pathways.

Megacities-defined as cities with populations greater than ten million-are of special significance here because of the challenges that arise at this scale due to the complexity of interactions between human needs and ecological limits. Several megacities where populations have grown rapidly are already water stressed, with access to water closely intertwined with deeply embedded socio-spatial inequities. As the population continues to expand, these megacities are increasingly relying on tapping into new and often distant water sources [5], which exposes these cities to new types of uncertainties and has major political repercussions coupled with wide-ranging ecological impacts as water is diverted and transported over large distances [6]. 
These large-scale dynamics that link these cities to the wider regions-coupled with the dynamics that play out within the metro scale-raise several interrelated governance challenges, including the following: a) overlapping (and often conflicting) jurisdictions that do not match well with natural resource boundaries; b) coupling of water with other urban management issues related to land use, housing, basic service provision, and environmental management; c) coordination across actors operating at different levels (municipal, state, and federal); and d) conflict between alternative framings of water as an economic, ecological, and social good, which is also increasingly being recognized as a human right.

While these governance challenges characterize most megacities around the world, in this paper, we are specifically interested in exploring the juxtaposition of these challenges with the multifaceted pressures and conditions of development in megacities of the global south. This juxtaposition is important to understand because, as argued in a recent perspective piece in Nature Sustainability, "urban issues in the global south are distinctly and statistically different from those in the global north, but our current urban knowledge is predominantly shaped by research on and from the global north" [7] (p. 341). The seriousness of this limitation is underscored by the fact that twenty-four of the world's thirty-one megacities are in the global south and that the ten new anticipated megacities to be added by 2030 will also emerge there [8]. In these cities of the global south, a critical challenge for urban sustainability relates to building resilience for the estimated billion urban dwellers who live in informal settlements and who account for more than half of the city's population and for much of its labor force [9]. There is an urgent need for new theoretical perspectives that are based on in-depth case studies, which reflect the plurality of conditions found in these cities $[7,10]$.

In this paper, we conduct a comparative analysis of water sustainability in two major megacities of the global south: the Metropolitan Region of São Paulo (referred to as MRSP, to distinguish it from the city or state of São Paulo) and the National Capital Territory of Delhi (NCT Delhi, or Delhi, subsequently). In the urban sustainability literature from the global south, a lot of attention has been devoted to vulnerabilities of coastal cities to sea level rise [8]. Through our selection of non-coastal megacities facing acute water stress, we aim to direct attention to the systemic sources of vulnerabilities and governance challenges that arise due to the coupling of social and ecological factors at the megacity scale. Both of our selected cities are situated along major rivers and depend on complex inter-basin water transfers, thus serving as highly relevant comparative examples of the transboundary governance challenges highlighted above, together with the challenges that arise within the metro scale due to the varied types of settlements (formal and informal) within their boundaries. MRSP with an estimated population of 21.6 million in 2018 and Delhi with 19.4 million are among the most populous megacities in the world. Both cities also have highly diverse populations with deeply embedded economic and social inequities that have both shaped and been shaped by access to basic services. However, interestingly, both cities have followed quite different trajectories in terms of the development of their water infrastructure and institutions. These different trajectories reveal varied sets of water-related risks and associated governance challenges and responses that we focus on in this paper.

Given the coupling of social and ecological factors and relationships in these cases, the theoretical perspectives that underlie our study are broadly inspired by the body of work on social-ecological systems (SESs). Several different frameworks, models, and theories have been suggested to understand SESs. A notable example here is the Systems Approach Framework (SAF), which has been recently applied, tested, and refined to support decision making for coastal and marine systems across 18 sites in Europe [11]. This body of work has highlighted some of the challenges that researchers encounter when "seeking to apply systemic integration concepts in 'arenas of practice"' [11] (p. 2115). Some of these challenges in practical applications arise from not fully grasping the contextual realities. In order to systematically study the plurality of conditions and modes of governance in our study cities, we draw on the SES framework suggested by Ostrom and colleagues [12,13]. Ostrom's SES framework consists of a set of core subsystems relating to the social and ecological dimensions, with associated variables organized within a multilevel, nested structure This nested structure supports finely grained analyses 
of social and ecological conditions, which is the chief strength of the SES framework [14]. The work by Ostrom and her colleagues shows how this framework can be used to integrate concepts and theories across different disciplines and to organize research from disparate empirical settings [12,13].

The specific objectives of this paper are, first, to develop an urban water SES module within the broader SES framework proposed by Ostrom based on the findings from our empirical research and, second, to apply this module to delve deeper into the specific challenges related to urban water sustainability in our study cities. We develop this module by starting with the core subsystems and the full range of embedded variables and processes in Ostrom's framework and, then, adding (or eliminating) variables that, based on our empirical work, were found to be potentially the most (or least) influential in explaining the dynamics of the water system and its governance. We combine these detailed, variable-oriented analyses with the process-oriented descriptive case studies approach that describes how institutions emerge and change, influencing outcomes [14].

We show in this paper how our module provides a richer characterization of the complexity of urban systems than the relatively sparse representation generally found in water reform studies that focus almost exclusively on the technological and/or economic aspects and consequently come up with cure-all solutions (or panaceas), like "building more dams," "digging deeper wells," or "getting the prices right." As this module illustrates, characterizing the problem of urban unsustainability as an imbalance between demand and supply is far too simplistic; instead sustainability outcomes are shaped by a complex yet discernable combination of settlement trajectories, urban planning choices, enabling and constraining governance structures, and uneven human capacities. We illustrate these issues through a structured process of context-specific inquiry, using our module as an analytical and diagnostic tool in order to identify and evaluate critical factors that might be missing or undeveloped in a particular setting. Finally, we show how the resulting insights can be used prescriptively to identify cross-learnings and practical lessons that could help practitioners in our study cities and elsewhere transition to more sustainable systems.

\section{Theory and Methods}

This paper is a product of several different (but related) long-term research projects carried out between 2009 and 2015 on the intersections between urban water sustainability and human rights in MRSP and Delhi. Over the course of the project, we encountered multiple layers of complexity that underlie the water systems of these megacities. In order to unpack this complexity and to better organize the data, we drew on Ostrom's SES framework as a first point of entry to identify key variables and relationships discussed in the literature on urban water sustainability. Ostrom's SES framework was originally developed to study local common pool resources in relatively small-scale (largely rural) settings. It has subsequently been modified to study a wide variety of sustainability problems [14]. We found that, although its structure was broadly useful, we needed to modify it to be meaningful and relevant for large metropolitan settings.

In order to systematically modify this framework to serve as an integrative reference for the comparative study of water sustainability in our two cities, as well as more broadly, we followed the systematic combining approach [15]. This is a mixed inductive and deductive approach, wherein previously developed concepts/frameworks are used as a guide to enter the empirical world but the framing of research then evolves in light of unanticipated ground realities and the framework is successively modified and refined in an iterative manner. This provides a way to critically evaluate existing and emerging constructs against ongoing observations in order to yield new theoretical and empirical insights.

Our field visits suggested that it would be valuable to unpack and probe deeper into some variables of Ostrom's framework while eliminating others as nonsignificant. The urban water SES module, shown in Figure 1, is the product of this iterative process. The term "module" is used here to emphasize the idea that what we are proposing is derived from and follows the same general structure as Ostrom's SES framework but is customized to meet certain specific needs. In technological design 
theory, modularity is commonly used as a way to manage complexity and to enable parallel work that can be interfaced with the whole [16].

The original SES framework in Reference [12] consists of the following four core subsystems: resource units, resource systems, governance, and users. Each of these subsystems is embedded within a wider social, political, and economic setting and linked to other social-ecological systems at higher scales (such as the river basin or watershed) to create a nested structure. These four subsystems, through their interactions, produce outcomes that iteratively affect the components of the various subsystems. Based on our field observations, we developed an urban water SES module (as shown in Figure 1) that consists of the following four core subsystems: (i) water resource and infrastructure (WRI); (ii) settlements (S); (iii) governance (G); and (iv) actors (A). Compared with Ostrom's SES framework, the $G$ subsystem in our module is defined in almost the same way, while the definitions of the WRI and A subsystems have been modified, and S is added to better account for the urban context, as we explain in detail below.

Political, economic and demographic settings

$\uparrow$

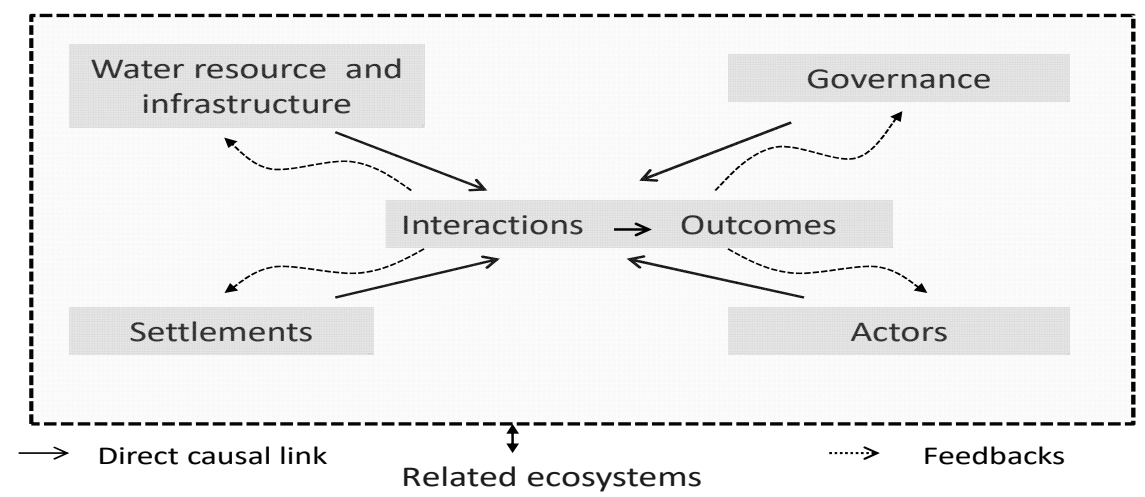

Figure 1. Urban water social-ecological system (SES) module (based on Ostrom, 2007).

The governance subsystem is defined in the same general way as in Ostrom's SES framework by the varied institutions (including rules, norms, and policies) that are used by actors to interact with each other in the provision and appropriation of the resource and infrastructure system. The water resource and infrastructure subsystem can be understood as the aggregation of two core subsystems in Ostrom's formulation-namely, resource units and resource subsystems. This is consistent with some recent applications of the SES framework [17] and our own empirical observations, which suggest that, in urban areas and particularly in large metropolitan areas, it is difficult to define a single, clearly bounded resource system. Often, water is transported into urban areas from large distances, and physical infrastructure is critical in terms of how it modifies, combines, and transforms the underlying characteristics (such as volume, flow, quality, and distribution) of the multiple sources of water within the urban landscape. Given the importance of infrastructure, we have also expanded Ostrom's original subsystem of users to include infrastructure providers, regulators, enforcers, and other relevant state and non-state actors who are defined in relation to the critical functional domains important for water and sanitation service (such as provision, financing, regulation, and service delivery). This expanded subsystem is labeled as "Actors."

Our settlements subsystem has no direct equivalent in the SES framework and has been added to better capture the complexity of urban landscapes. Cities are distinguished from the more widely studied cases of local commons in rural areas by the diverse types of settlements that emerge as a consequence of population growth and movement in cities. The different types of settlements can be defined by their security of tenure (which in turn depends on history of settlement, zoning regulations, degree of formality, or legality), demographic characteristics (racial/ethnic/caste composition), housing characteristics, and population density. These characteristics are often highly correlated with each other, 
creating distinct patterns of spatial heterogeneity within the urban landscape. An important element of the distribution of settlements is residential segregation, which is defined as the unequal spatial distribution of population groups (defined by income, class, caste, ethnicity, or racial background) within the urban agglomeration [18]. Residential segregation often manifests in diverse ways across different metropolitan areas. For instance, in some megacities, one may observe a core-periphery pattern with marginalized populations concentrated in the outskirts, while in others, one may observe marginalized populations in localized pockets all across the metropolitan area [19]. The severity of deprivation as well as their ecological consequences may be different depending upon whether these settlements without access are isolated or are close to settlements with established infrastructure. The possibilities for social movements to emerge are also likely to be different depending on how the settlements are distributed. Further, the appropriate technology for providing water and sanitation may differ depending on the housing characteristics and density. For example, conventional grid-based piping and sewage systems may not be feasible to be installed in highly dense, slum settlements. All of these arguments underscore the need to incorporate a settlement subsystem in the module and to study its relationship with other core subsystems.

The final box in the SES framework, labeled as "interactions and outcomes" in Figure 1, refers to the interrelationships and feedbacks among these subsystems that help explain the functioning of the overall system and the outcomes of interests-such as coverage rates for water and sanitation services (WSS), water quality, and resilience of the system.

To ensure that we get rich contextual details on each of the subsystems in the module, we collected information from both primary and secondary data sources. Secondary data consisted of policy documents, public utility reports, court cases, media pieces, and census data collected electronically and through in-country archives. Primary data was collected through semi-structured interviews with around 30 key informants, with interviews lasting about 30-45 min. A purposive sampling approach was followed in order to specifically target relevant informants in each of the following categories which correspond to the different subsystems in our module (as shown in Figure 1): (1) representatives of nongovernmental and community groups who work in varied types of settlements, (2) staff working at different levels in water and sanitation agencies with deep knowledge about the history and functioning of water resource and infrastructure subsystems, (3) lawyers and judges with intimate knowledge of the governance subsystem, and (4) other key actors-such as researchers and members of various citizen groups with tacit and experiential knowledge regarding the overall functioning of the water system. Each of these groups of informants was asked to identify the key factors and processes that constitute their respective subsystem as well as their perspectives on the barriers to and opportunities for improving water sustainability in their city. Respondents were contacted directly and through snowball techniques, where current respondents were engaged to recruit new ones.

\section{Applying Urban Water SES Module to the Case of MRSP and Delhi}

Based on our empirical findings, we developed the urban water SES module, which consists of a set of variables and processes that we found to be key in explaining the complexity of sustainability challenges and in enabling a system-based comparative assessment of the trajectories of urban water provision and management in our study cities. In this section, we unpack each of the different subsystems (S, WRI, G, and A in Figure 1) within the urban water SES module for our two study cities. Each of the subsystems in Figure 1 is embedded within a wider social, political, and economic setting and linked to other social-ecological systems at higher scales to create a nested structure. We begin with a discussion of this broader setting and then take a deep dive into the individual subsystems and their interactions. Table 1 lists the different variables we have identified as being relevant within each of the subsystems and compares them across the two cases. Table 2 lists some major historical events that shaped the evolution of these variables. 
Table 1. Selected key variables of urban water SES module: Metropolitan Region of São Paulo (MRSP) and National Capital Territory (NCT)-Delhi ${ }^{1}$.

\begin{tabular}{|c|c|c|}
\hline Key Variables & MRSP & NCT-Delhi \\
\hline \multicolumn{3}{|c|}{ Political, economic, and demographic settings (S) } \\
\hline Economic development & $\begin{array}{l}\text { Major industrial center } \\
\text { Import substitution led industrialization }\end{array}$ & $\begin{array}{c}\text { Nation's capital } \\
\text { Economic structure dominated by government and related services }\end{array}$ \\
\hline $\begin{array}{l}\text { Population } \\
\text { Census 2010-11 } \\
2018 \text { (estimate) }\end{array}$ & $\begin{array}{l}19.7 \text { million } \\
21.57 \text { million }\end{array}$ & $\begin{array}{l}16.8 \text { million } \\
19.483 \text { million }\end{array}$ \\
\hline Political stability & $\begin{array}{l}\begin{array}{l}\text { Democratic rule since 1986, with intermittent periods of democratic rule } \\
\text { before }\end{array} \\
\text {. }\end{array}$ & $\begin{array}{l}\text { Democratic rule since } 1947 \\
\text { National emergency from } 1975 \text { to } 77\end{array}$ \\
\hline \multicolumn{3}{|c|}{ Related Ecosystems } \\
\hline Climate patterns & Increasing intensity and frequency of extreme events (droughts and floods) & More intense monsoon events and higher frequency of droughts \\
\hline Flows into and out of focal SES & Deforestation and pollution in the Piracicaba-Capivari-Jundiaí (PCJ) basin & Deforestation and pollution in the Yamuna basin \\
\hline \multicolumn{3}{|c|}{$\begin{array}{ll}\text { Settlements subsystem } \\
\end{array}$} \\
\hline Area & $8000 \mathrm{sq} \cdot \mathrm{km}$ & 1483 sq.km. \\
\hline Population density & $\begin{array}{l}2469 \text { people per sq. km (2009) } \\
2714 \text { per sq. km (2018) }\end{array}$ & $\begin{array}{l}11,297 \text { people per sq. } \mathrm{km}(2010) \\
13,138 \text { per sq. } \mathrm{km}(2018)\end{array}$ \\
\hline Urban planning & $\begin{array}{c}\text { First plan: } 1962 \\
\text { Top-down design and implementation }\end{array}$ & $\begin{array}{c}\text { First masterplan: } 1971 \\
\text { Top-down design and implementation }\end{array}$ \\
\hline Types of informal settlements & Types: favelas, cortiços, ocupação, or invasão & Types: slums, Jhuggi Jhopri, and unauthorized colonies \\
\hline Distribution of informal settlements & Concentrated in peripheries and in protected watersheds & Distributed all across metro area and in protected watersheds \\
\hline \multicolumn{3}{|c|}{ Water resources and infrastructure subsystem } \\
\hline Annual rainfall & $1317 \mathrm{~mm}$ & $612 \mathrm{~mm}$ \\
\hline Sources of water supply for water utility & $\begin{array}{l}80 \% \text { surface water } \\
20 \% \text { groundwater }\end{array}$ & $\begin{array}{c}\qquad 8 \% \text { surface water } \\
12 \% \text { groundwater (likely to be underestimated due to incomplete data) }\end{array}$ \\
\hline Temporal pattern in groundwater & \multicolumn{2}{|c|}{ Groundwater depletion and an increase in pumping costs } \\
\hline $\begin{array}{c}\text { Storage characteristics (RS8): Major surface water } \\
\text { projects }\end{array}$ & Eight water production systems: the largest is the Cantareira system & $\begin{array}{l}\text { Three major water production systems: the largest is based on River } \\
\text { Yamuna }\end{array}$ \\
\hline Size: Water treatment and supply capacity & 5600 million liters per day (2007) & 3887 million liters per day $(2012)^{b}$ \\
\hline \multicolumn{3}{|c|}{ Governance subsystem (GS) } \\
\hline Property rights: surface water & \multicolumn{2}{|c|}{ State subject (unless water lies between two state boundaries, which is then a federal subject) } \\
\hline Property rights: groundwater & Considered mineral resources under federal jurisdiction & Considered property of overlying landowner \\
\hline Responsibility for water \& sanitation service & Municipal governments until 1968; thereafter transferred to state level & Central government until 1992; thereafter transferred to municipalities \\
\hline Level of decentralization & River basin level & Neighborhood level \\
\hline \multicolumn{3}{|c|}{ Actors subsystem (A) } \\
\hline Main actors and their functions & See Table 3 & See Table 3 \\
\hline \multicolumn{3}{|c|}{ Outcomes related to water and sanitation services } \\
\hline Access to piped water $(\%)$ & & \\
\hline 1970 & $63 \%$ & $70 \%$ \\
\hline
\end{tabular}


Table 1. Cont.

\begin{tabular}{ccc}
\hline Key Variables & MRSP & NCT-Delhi \\
\hline 1990 & $96 \%$ & $75.8 \%$ \\
\hline 2000 & $98 \%$ & $75.3 \%$ \\
\hline Latest available & $\sim 100 \%(2018)$ & $83 \%(2018-19)$ \\
\hline Households connected to sewage treatment plant $(\%)$ & $75 \%(2017)$ & $55 \%(2016)$ \\
\hline
\end{tabular}

Notes: ${ }^{1}$ Data sources and explanations are referenced in the text.

Table 2. Major events in the histories of MRSP and Delhi.

\begin{tabular}{|c|c|c|}
\hline Period/Year & MRSP & Delhi \\
\hline Before 1920 & Independence from Portuguese rule (1822) & Under British rule, Delhi was declared capital of British India (1911). \\
\hline 1920-1940 & $\begin{array}{l}\text { São Paulo emerged as major industrial center. } \\
\text { Rapid population growth } \\
\text { Major hydropower projects initiated }\end{array}$ & $\begin{array}{l}\text { Government services sector grew under British rule. } \\
\text { Slow population growth } \\
\text { No major hydropower projects }\end{array}$ \\
\hline 1940-1960 & $\begin{array}{l}\text { Import substitution industrial (ISI) policy aggressively pursued } \\
\text { Continued high population growth }\end{array}$ & $\begin{array}{l}\text { Delhi was declared the capital of independent India (1947). } \\
\text { Rapid population growth in late 1940s due to large flow of refugees }\end{array}$ \\
\hline 1960s & $\begin{array}{c}\text { Military coup in } 1964 \\
\text { Rapid industrial growth } \\
\text { Growth in informal settlements in peripheral areas } \\
\text { The National Water Supply and Sanitation Plan (PLANASA) was created as the first } \\
\text { federal government initiative in water \& sanitation }\end{array}$ & $\begin{array}{l}\text { First Master Plan of Delhi (1962) } \\
\text { Rapid expansion of the government services sector and slow growth in the industrial sector }\end{array}$ \\
\hline 1970s & $\begin{array}{c}\text { First integrated Metropolitan Development Plan (1971) } \\
\text { SABESP formed (1973) } \\
\text { Watershed Protection Law (1976) } \\
\text { Continuation of rapid growth in informal settlements in the periphery } \\
\text { Early democracy movements }\end{array}$ & $\begin{array}{l}\text { National emergency (1975-1977)—democratic freedoms curtailed } \\
\text { Slum eviction and relocation policies strongly enforced }\end{array}$ \\
\hline 1980s & $\begin{array}{c}\text { End of military regime (1983) } \\
\text { Transition to a popularly elected government in } 1986\end{array}$ & Problem of slums recognized but no consistent policy for housing \\
\hline 1990s & $\begin{array}{l}\text { Water resource management plan (1991) involved decentralization and greater scope for } \\
\text { participation. } \\
\text { Neoliberal economic policies were implemented in 1995-1996. } \\
\text { Water capture area protection law (1997) supported the engagement of municipalities } \\
\text { and civil society organizations through creation of watershed organizations. }\end{array}$ & $\begin{array}{c}\text { Union Territory of Delhi was provided special status as NCT. } \\
\text { Decentralization reforms (1993) gave greater autonomy to local bodies and encouraged citizen } \\
\text { participation. } \\
\text { Structural adjustment reform with stronger push for Neoliberal economic policies was implemented } \\
\text { (1992). } \\
\text { Rapid growth of small scale and unorganized manufacturing units }\end{array}$ \\
\hline 2000s-present & $\begin{array}{l}\text { Economic growth stabilization and restructuring } \\
\text { Slowdown in population growth } \\
\text { Basic Sanitation Law (2007) } \\
\text { Drought in MRSP (2014-15) }\end{array}$ & $\begin{array}{l}\text { Economic growth continues at a rapid pace. } \\
\text { Continued population growth } \\
\text { Unauthorized colonies regularization } \\
\text { Clean India Mission (2013-19) }\end{array}$ \\
\hline
\end{tabular}




\subsection{Political, Economic, and Demographic Setting}

Although engineering and hydrological considerations have long dominated thinking about water systems, there is a growing recognition that provision of basic services is a deeply political matter. However, it is less clear as to how different political institutions and processes contribute towards ensuring affordable access to all sections of the populace. One factor, arguably, is the degree of democratic responsiveness of a political system. India has been democratic since 1947, when it became independent from British rule. Brazil had a transition to democracy in 1986 following 22 years of military rule. The mere presence of formal democratic institutions, however, is insufficient to ensure the emergence of basic service provision. Also important is what is often referred to as the "practice of democracy" [20] (p. 2). The "practice of democracy" is most visible in forms of participation (who participates, via what channels, and how demand for public services is articulated) and substantive outcomes (how far popular inputs are translated into concrete outputs). The participative spaces for citizen engagement with local representatives and the relative autonomy and capacity of the local urban bodies to respond to citizen demands have differentially influenced the development of basic services in the two cities, as we describe below.

The strong, centralized systems of governance that characterized both Brazil and India through much of their history gave way in the late 1980s and early 1990s to the decentralization reforms implemented in many nations of the global south. These reforms were ostensibly designed to give greater budgetary and decision-making autonomy to local governments, but there were several challenges. In the case of India, until the passage of the Constitutional Amendment Act (CAA) in 1993, most states in India did not even hold regular municipal elections and the autonomy of urban local bodies was minimal [20]. In Brazil, local governments long enjoyed a relatively higher degree of political and fiscal autonomy [20], with municipalities generating half of their revenues locally [21]. In wealthy São Paulo, resources were less of a constraint than in the relatively poorer Delhi, though administrative and fiscal capacity and accountability deficits could be found within local state agencies in both cities.

Relative to other major Indian cities, local governance in Delhi is further complicated by its position as the nation's capital and as a Union Territory. In 1956, largely for security reasons, important issues related to urban governance in Delhi were placed under the central government and the roles of elected local officials in city affairs were severely limited. In 1991, the Union Territory of Delhi was renamed the National Capital Territory (NCT) of Delhi and a directly elected legislative assembly was introduced. However, the critical functions of land management and city planning, which underpin a number of local governance and infrastructure issues, continue to be under the purview of the central government [22], creating unique challenges for water provision and management as we shall see in later subsections. Many urban scholars have regarded this lack of local control over land management in Delhi to be a major administrative limitation [22]; one that cities like São Paulo, where governance over land is largely local, do not face.

Economic development trajectories structure both the long-term demand for water resources and the financial capacity to meet this demand. São Paulo's trajectory was characterized by rapid industrial growth that accelerated throughout the twentieth century, particularly in the 1960s and 1970s, when import substitution industrialization policies were aggressively pursued. This developmental path imposed huge demands on energy and water services, through both hydropower projects and urban expansion, and was a critical driver of large-scale, capital-intensive water resource development in the region [23]. As the political capital of the country, under successive regimes, Delhi's economic structure has been dominated by the government sector and other service-based activities, such as real estate, telecommunications, health and community services, and retail [22]. This type of economic structure demands relatively less energy and water than in the case of MRSP and, as we shall see, has been relatively less dominated by captive demand from powerful industrial actors.

Economic growth in both cities has attracted migrants from smaller towns and rural areas, but their population growth trajectories differ significantly, as shown in Figure 2. While population 
levels influence overall current demand for water, varying rates of population growth increase the indeterminacy of future needs and may make it more challenging to balance investments in infrastructure (which are long term in nature) with rapidly changing population numbers. Moreover, whenever there is an imbalance between supply and demand, the shortfall is not shared proportionally across the population. Often, the poorest segments of the population bear the heaviest burden, as happened during the decades of the 1970s in MRSP and of the 1990s in Delhi, when there was very high population growth and a sharp fall in access to basic services in poorer neighborhoods. Even relatively short periods of imbalance in supply and demand can result in crossing of critical environmental thresholds and in irreversible damage to underlying ecosystems, as we discuss next.

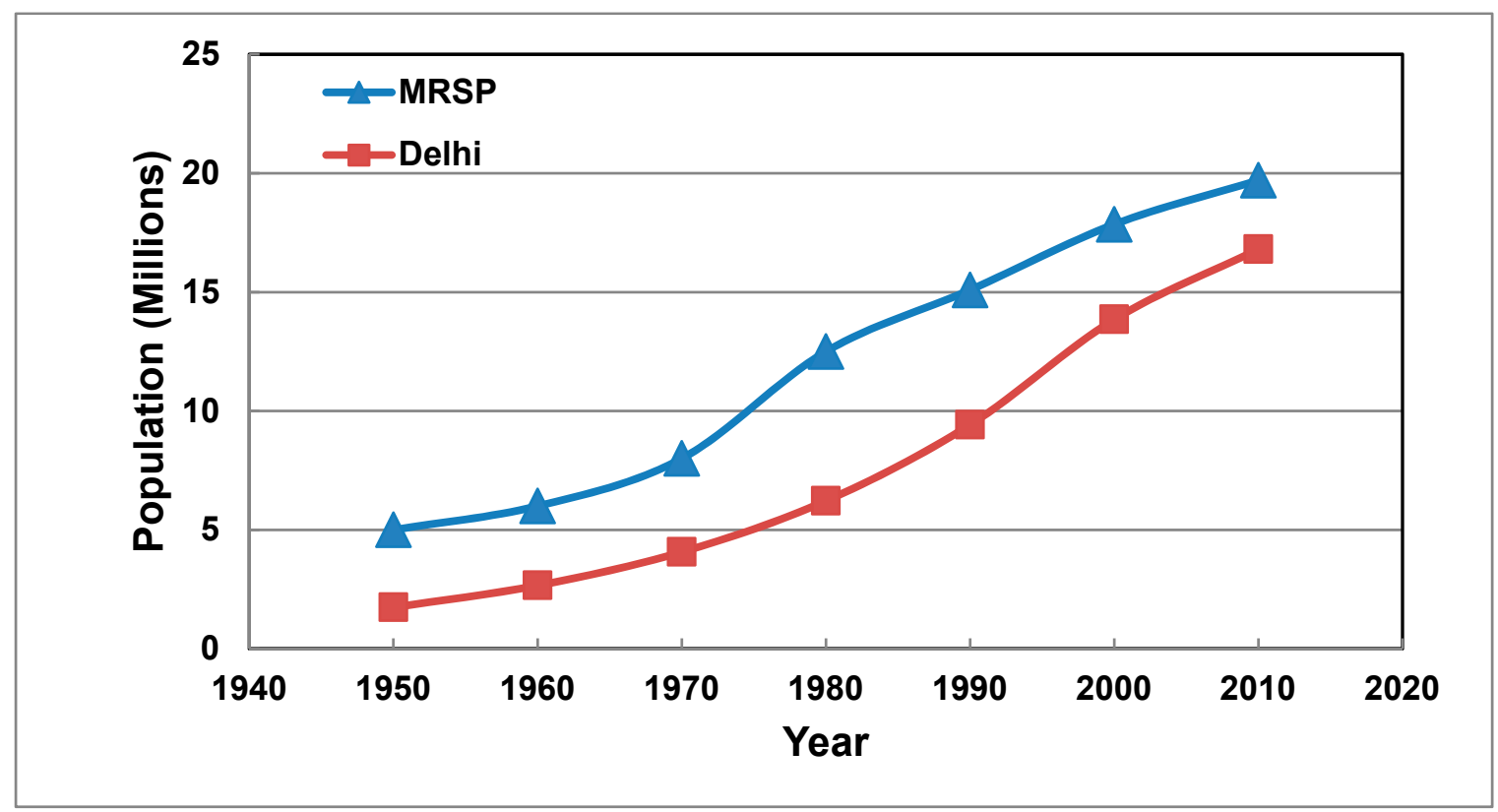

Figure 2. Population trends in MRSP and Delhi (based on data from population census).

\subsection{Linked Ecosystems}

Both cities depend on the health of major watersheds for their water supply: in the case of MRSP, it is the Piracicaba-Capivari-Jundiaí (PCJ) and Upper Tietê basins, and in the case of Delhi, it is the Yamuna basin. Forest loss in these watersheds has contributed to soil erosion, polluted waterways, change in seasonal water flow, and a decline in quality of water that flows into these cities. In addition, in the case of MRSP, precipitation itself has been linked to the condition of the distant Amazon forest. Using data from 28 weather stations in two areas of Brazil, a recent research study found that "winds coming from the Amazon rain forest carry more water than winds coming from deforested areas and arriving at the same station" [24] (p. 1). This research along with other studies conducted over the past two decades show how the Amazon's changing climate has implications far beyond its boundaries $[25,26]$. Responsive urban water governance increasingly depends on incorporating the effects of changes in linked ecosystems.

Having described the broader contextual setting in both cities, we turn next to unpacking each of the subsystems of the SES module.

\subsection{Settlements Subsystem}

In cities across the global south, access to water and sanitation services (WSS) is not uniformly distributed and is often closely linked to the type of settlement. In order to understand this variation in settlement types, researchers have often attempted to build a typology of settlements, but according to the practitioners that we interviewed, this can be misleading as neat binaries of formal/informal, 
legal/illegal, or even rural/urban do not exist. These categorizations not only are very fluid and uncertain in the highly dynamic environment of these cities but also are often politically defined and subject to political manipulation. For instance, as Reference [27] (pp. 151-152) points out, the legal definition of Sao Paulo's hinterlands as largely rural until the mid-1960s "meant that developers could forego the requirements of urban legislation in subdividing the land. As these sub-divisions grew and were incorporated into the urban area of the municipality by new legislation, they became instantly illegal according to the very statutes that had been ignored." Furthermore, settlements designated as "rural" were not entitled to the same municipal resources as urban and either had to provide for these on their own or had to struggle politically to acquire them. These ambiguities and fluidities in categorization underscore the need to probe deeper into the history of these varied settlements in order to understand their changing status related to access to WSS, as well as to explain the emergence of unintended consequences.

In both cities and particularly in the case of MRSP, most of the population growth happened before the beginning of formalized city planning and followed a rather chaotic settlement pattern. By the time that the first Integrated Metropolitan Development Plan for MRSP was published in 1971, the population had been growing rapidly for nearly four decades and was already more than 9 million. A large part of the population growth happened in the peripheral areas with relatively lower population density than the core and with almost no infrastructure [28,29]. The root cause of peripheralization lay in rising poverty and unemployment, which made established areas of the city unaffordable for large sections of the population. Moreover, absence of state investments and accompanying regulations meant that development was largely driven by unregulated private real estate markets and that land speculation was rampant [28]. In the peripheral areas, around 70 percent of all homes in the 1980s were built through self-help methods in settlements situated in illegal subdivisions [23]. Depending on the initial access to land, two kinds of settlements could be distinguished: those based on land purchase or those based on land seizure. The former is referred to as "loteamento" (subdivision), and the latter is referred to as "favela" or, if acquired through organized groups such as Landless Movement, as ocupação or invasão (occupation or invasion) [28]. By 1991, around 11 percent of the population lived in favelas compared to only 1 percent in 1973 [23], with limited access to basic services. Informal housing in the form of cortiços (or rented housing units in abandoned buildings) in the city center also became common.

Informal settlements also grew in protected watersheds [30]. The Watershed Protection Law of 1976 deterred residential settlements in 54 percent of the metropolitan area in order to protect critical water sources for urban use. However, the law was not enforced effectively in part because it fell under state jurisdiction while land occupation policy and zoning fell under municipal jurisdiction [30]. Poor residents were attracted by what seemed like "available land" that was not under the same competition as land in the core of the city. Proximity to industrial parks and, hence, jobs was another major factor driving population growth in these areas. Given the precarious legal status of these dwellings, provision of basic services had been problematic in these types of settlements [29]. In particular, the Water Protection Law explicitly prohibited building sanitation infrastructures, so sewage from these new settlements was discharged directly into the reservoirs, leading to significant water quality and public health problems. In Section 3.6, we explore how this situation began to change with the pro-democracy movements of the 1980s.

Delhi's first Master Plan was implemented much earlier in its urbanization history, in 1962. However, even in this case, it was not early enough to avoid a decade of chaotic growth in slum settlements. Ironically, the Master Plan in Delhi introduced a new set of problems as the main agency responsible for land planning and procurement (Delhi Development Authority) functioned under the jurisdiction of the federal government while the Slum Department was under the local government [21]. Problems of coordination among these agencies and lack of local control and accountability contributed to a wide divergence between well-intentioned policy statements and their implementation. Thus, for instance, the first Master Plan envisaged resettlement of slum households to designated sites in 
the outskirts of the city. However, the resettlement could not proceed as planned because of lack of financial resources and availability of suitable land to resettle the households [31]. Subsequently, there were various revisions to the requirement about the minimum size of plot to be allocated and rules regarding the leasehold under different political regimes.

The overall effect was that slum relocation became a highly politicized and a rather ad hoc policy, despite good intentions. The impact at the household level was varied as some households did resettle permanently while most others sold off their new homes because of lack of employment opportunities in the vicinity and settled back into their former slum dwellings in the city. The growth rate of Delhi's slum population during 1981-1994 was 13 percent per annum as compared to the 3 percent growth in the rest of the population [32]. The growth rate has slowed somewhat since then, but according to the latest 2011 census, there were 1.9 million slum residents in Delhi, constituting around $11 \%$ of the population [32]. From time to time, some of these slums have been notified (i.e., given legal status) which clears the path for basic service provision. However, the rather ad hoc process of designation of specific slums as "notified" makes the task of long-term planning for water resources and infrastructure provision very challenging.

It is not just settlements housing the poor or designated as "slums" that create challenges for public utilities. In Delhi, developers purchased land from farmers in outlying villages and subdivided and sold unserviced land in violation of the Master Plan as well as other land use regulations and building standards [18]. Unlike in slum settlements, the majority of residents in these settlements had legal titles to the land and did not belong to low-income groups [18]. However, because these settlements were "unauthorized," there has been no consistent policy regarding provision of basic services. Under political pressure, some of these "unauthorized" settlements have been regularized over time, but service provision is generally lagging. Similarly, in MRSP, sale of land by private developers in violation of official city plans also occurred, specifically in environmental protection areas, where the public water company did not initially have a mandate to provide services. This caused problems, both practical and legal, for the utility [33].

Our characterization of the evolution of different types of settlements vis-à-vis planning in the two cities illustrates the concept of urban informality that is often used to distinguish the process of urbanization in the global south. As Reference [34] argues, "informality is not a separate sector" distinct from the formal and it is not a concept that applies only to the poor or the marginalized (p.148). Rather, it is an "organizing logic, a system of norms that governs" the urbanization process itself [34] (p. 148). As our discussion illustrates, this "organizing logic" underlies the evolution of varied informal settlements through the creation of affordability in the absence of and/or suspension of planning and regulations in our two study sites. The varied settlement types in Delhi and MRSP, with their unique "concretizations of legitimacy" [34] (p. 149), differentially influence popular expectations and institutional mandates regarding basic services. The discussion also underscores why and how the challenges of service provision extend beyond technical or economic considerations to political and legal struggles, which have been given relatively less attention in the water supply literature, as we discuss next.

\subsection{Water Resources and Infrastructure Subsystem}

Given the rapid rate of growth of settlements in both cities, city administrators have been under constant pressure to search for new sources of water and to plan for investments in physical infrastructure (e.g., pipes and treatment plants) to deliver this water. In this obsession, what gets lost very often is systemic thinking about the different stages of the water cycle, beyond the provision of water. For instance, a recent comprehensive study of water systems in major cities of India found that almost $80 \%$ of the water that reaches households leaves as waste, yet there is no systematic planning for waste [35]. Most of this waste ends up back in the same sources of water (such as rivers and lakes) that provide for the city's needs, thus rendering these sources unsuitable, and further feeding the obsession for newer (and often more distant) sources of water. From a social-ecological perspective, 
urban water sustainability thus requires connecting the following nodes in the biophysical parts of the water system: (a) water sources and the health of watersheds in which these sources are situated; (b) the infrastructure related to transport, treatment, and delivery of this water; and (c) collection, treatment, and disposal of the wastes. These biophysical elements of the water system, which we consider in this subsection, are further connected with the human aspects (i.e., actors and governance systems) that we examine in the next two subsections.

Beginning with sources available within the metropolitan area, precipitation received is a critical factor. Delhi receives only $612 \mathrm{~mm}$ of rainfall annually, which is less than half of what MRSP receives $(1317 \mathrm{~mm})$; more importantly, the concentration of this precipitation in just a few months in Delhi raises a number of management challenges, which historically have been addressed through a vast network of natural and manmade water bodies for catching and storing water. The recent explosion of growth has threatened these water sources through encroachment and pollution. A recent assessment by the Delhi Government identified around 620 such water bodies and emphasized the need for proper mapping and restoration [36], but restoration efforts have been hard to implement given the complications of property rights and conflicts across jurisdictions. Instead, most water provisioning efforts have focused on getting water from neighboring states and on building the requisite infrastructure.

Like most other megacities, MRSP and Delhi both depend upon large interbasin transfers. Water is currently supplied to MRSP via eight water production systems, of which the largest is the Cantareira System (see Figure 3). There are long-standing tensions among water resource management units that span the Cantareira System, in part because of the authoritarian way in which the system was initially implemented under the military regime [23] and in part because of the incredible demand of MRSP itself. It is estimated that half of MRSP's 20 million inhabitants depend on the Cantareira System for their water supply [37], as do residents and businesses in neighboring municipal regions (which together form the São Paulo "macrometropolis"). Recently, this system has come under additional pressure due to unexpectedly low levels of rainfall and a resulting drought.

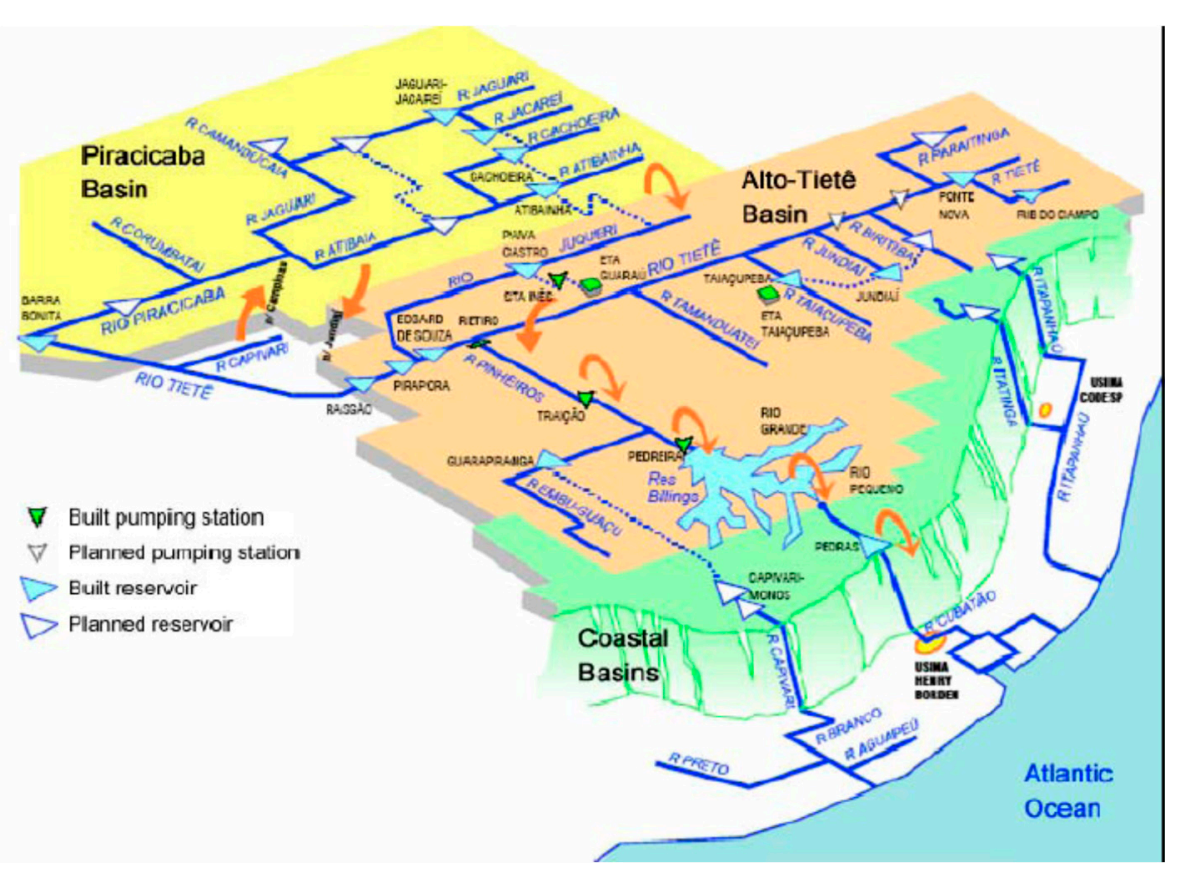

Figure 3. Water resource and infrastructure system in MRSP (Source: www.daee.sp.gov.br).

The other key water basin supplying MRSP, the Upper Tiete, is under even more duress than the Piracicaba Basin. With the emergence of São Paulo as a major industrial center, the development of water infrastructure in the Upper Tiete region was largely dictated by energy priorities [30]. At the core of this hydroelectric energy system were two reservoirs, Billings and Guarapiranga, built in the 1920s 
(Figure 3). In the late 1940s, the city sought to use Guarapiranga's waters to meet growing demand and, in exchange, agreed to return an equivalent quantity of water to the hydroelectric company in the form of sewage. This waste, discharged into the Tiete as it flowed through the city, transformed Billings into something like a "sewage stabilization reservoir" [30] (p. 170). The water-quality issues that are the legacy of this modification to meet the city's growing needs have been further exacerbated by occupation—legal and illegal—of the areas around the reservoirs, which has led to deforestation, storm water runoff, and silting, as well as sewage pollution due to lack of sanitation infrastructure [38].

Relative to MRSP, Delhi's water infrastructure was not as strongly driven by energy needs given the limited development of heavy industries in the region. Delhi lies along the banks of the River Yamuna, which flows along the eastern side of the city and has historically been the primary source of water (Figure 4). It was only in the latter half of the 1940s and 1950s, when the city population grew rapidly, that the Delhi government began seeking out new sources of supply in neighboring states (such as the Bhakra-Nangal dam in the neighboring state of Himachal Pradesh). The construction of new dams has come under strong opposition from environmental groups in recent years, particularly since the late 1980s. Ironically, this is also the time when Delhi's population has expanded rapidly, placing excessive stress on existing sources of supply.

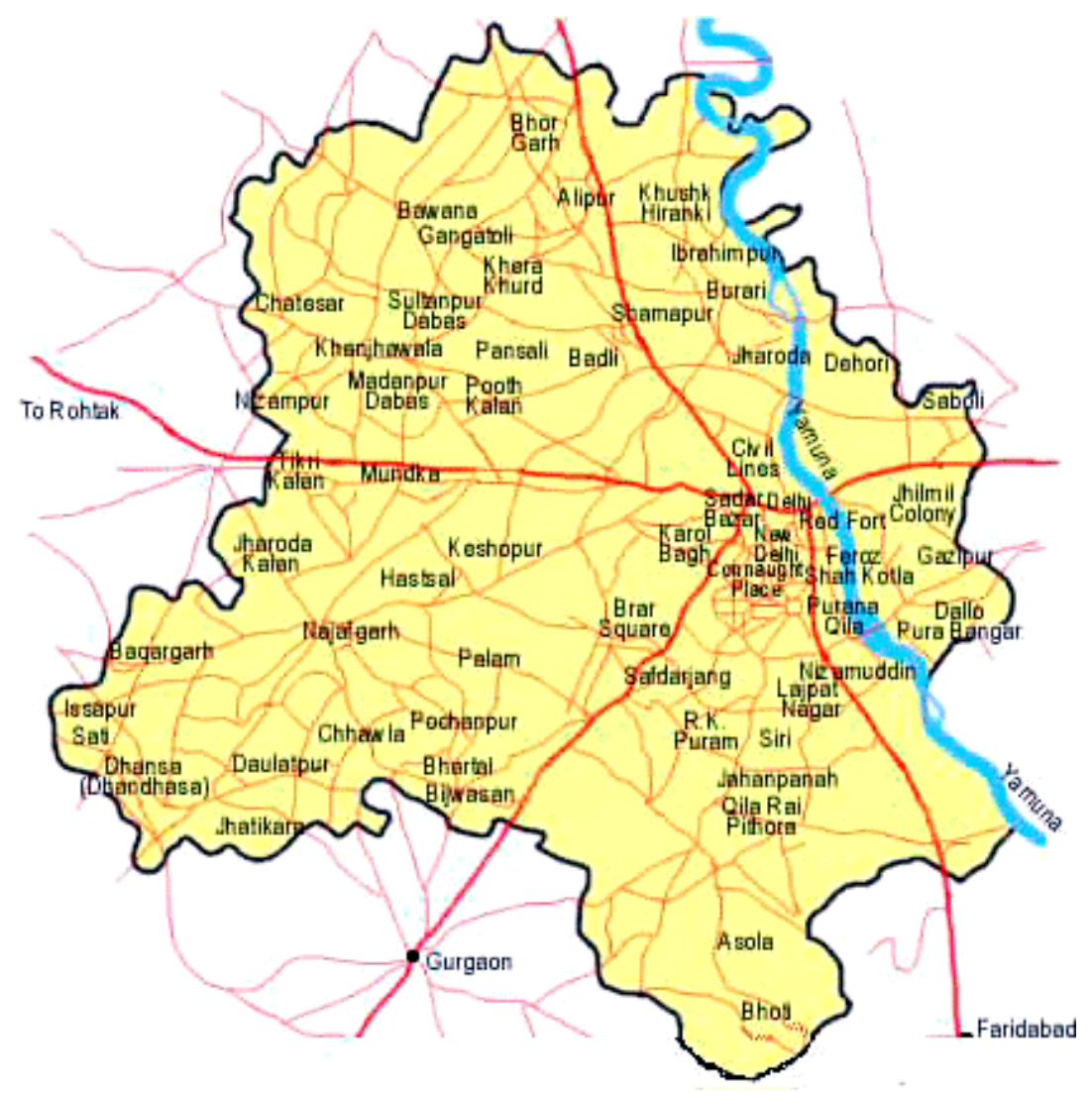

Figure 4. National Capital Territory of Delhi with River Yamuna on the eastern edge.

In both cities, groundwater provides an alternative source of supply and its use has grown rapidly in the past couple of decades. In MRSP, groundwater accounts for about $20 \%$ of the total supply, of which much goes to industry [39]. For residential supply, the city relies almost exclusively on surface water, though in the few municipalities not serviced by the state utility, local governments rely heavily on aquifers [30]. In Delhi, surface water sources are highly inadequate, even for meeting residential water needs. Groundwater use is very poorly regulated and the groundwater table has been falling rapidly in parts of Delhi, which raises serious concerns around sustainability of supply. Current estimates suggest that groundwater accounts for around $12 \%$ of residential water supply by 
public utility [40]. This does not include the largely unaccounted extraction by residents of informal settlements not serviced by the utility. In terms of water quality, as in the case of MRSP, flow of untreated sewage from the city and informal settlements along the Yamuna river and other water bodies have raised serious concerns about pollution.

Delivering water in megacities, with their huge populations spread over diverse settlements, entails another dimension of governance challenge related to distribution, maintenance, and oversight. As of 2006, MRSP's water utility operated eight water treatment plants, 159 pumping stations, and 198 urban reservoirs, with a combined average production capacity of 5600 million liters per day [41]. Delhi's water system is much smaller with 11 treatment plants and lower capacity (total of 3236 million liters per day in 2011-12). This falls far short of the 3861 million liters per day (60 gallons per person) that the Government of India considers adequate [36]. Leakage losses, not only in transmission from treatment plants to consumers but also via diversion through numerous illegal connections, were estimated to be around 32\% in MRSP and 52\% in Delhi in 2011 [35,42]. These realities draw our attention to the governance challenges at the root of seemingly technical water infrastructure issues. We turn to examining these next.

\subsection{Water Governance Subsystem}

The governance subsystem in the urban SES module can be conceptualized to consist of two sets of variables. The first set of variables relates to structure, which includes property rights and the administrative layout, jurisdiction, and responsibility of organizations at different levels (federal, state, and local). The second set of variables relates to processes: basis of decision-making, exercise of accountability and transparency, and forms of citizen participation. These two sets of variables are distinct but strongly interrelated. For instance, in terms of structure, a key distinction is often made in theory and practice between centralized and decentralized structures. Both cities have evolved from highly centralized water governance structures towards more decentralization but in very different ways in terms of which functions have been delegated and, consequently, the kinds of processes that these structures have enabled (or inhibited). The focus here is on governance institutions rather than specific actors, though these at times overlap; actors and their specific characteristics will be discussed in Section 3.6.

Starting with property rights structures, in both countries, surface water resources that lie within two or more states come under federal jurisdiction; otherwise, water is a state subject. Groundwater rights are not well defined in either country. In India, groundwater resources are regarded as property of the owner of the overlying land. Groundwater pumping was not regulated in Delhi until 1997, when groundwater depletion became severe and the Central Ground Water Authority (CGWA) was put in charge of regulating and controlling groundwater. In Brazil, groundwater is considered a mineral and is thus owned by the federal government, but much of the governance occurs at multiple levels. Overall, in both cities, groundwater continues to be very weakly regulated, and as a result, groundwater tables have been falling rapidly [30,35]. The exploitation of groundwater has been particularly severe in areas not serviced by public infrastructure, such as the unauthorized colonies and slum settlements in Delhi and the self-help settlements in MRSP.

In both cities, universal provision of water and sanitation services (WSS) is regarded as an important policy goal, with federal governments providing the overall policy direction and some funding. There are differences, however, in how the responsibility of provision and operation is split between state and local governments. In Brazil, WSS provision was primarily the responsibility of municipal governments until 1968 when the National Water Supply and Sanitation Plan (PLANASA) was created and when administration of WSS was transferred to the state level through the establishment of state WSS companies. Although the municipalities continued to own the services under the federal constitution, they now found themselves having to authorize the transfer of services to states or to risk losing access to funding through the National Housing Bank (BNH). In São Paulo, this led to the formation of the Basic Sanitation Company of São Paulo State (SABESP), established in 1973 as a 
state-owned water and wastewater concessionaire with mixed shares. In India, as mentioned before, the role of municipalities in WSS was almost nonexistent until the Constitutional Amendment Act in 1993, when states were asked to delegate responsibility for WSS provision to municipalities. In 1998, the Delhi Jal Board (DJB) was created as an autonomous agency responsible for WSS, but in practice, the Government of Delhi (and sometimes the central government) continued to exert significant influence on the administration as well as financial matters of DJB [22]. This institutional history helps set the context within which to examine the effectiveness and impacts of decentralization reforms that we discuss next.

As urbanization expanded, the command and control structure of water management with very limited set of monitoring and regulatory tools and almost no stakeholder participation became a serious handicap in both cities. In the case of MRSP, the growing public recognition of the links between deteriorating water quality and worsening public health outcomes became a major driver for change [29]. However, an important impediment towards resolving this situation was the lack of coordination among state level agencies such as Department of Water and Electrical Energy (DAEE (Departamento de Águas e Energia Elétrica); responsible for water concessions and dams), CETESB (State Environment Agency (Centro Tecnológico de Saneamento Básico); responsible for water quality), and the various municipal bodies responsible for land-use. Given growing concerns about water-quality issues and the escalating conflicts among the different water users in the state, a new statewide Water Law was passed in 1991 in São Paulo. The focus of this law was on decentralization and participation, with the river basin as the basic unit of planning. River basin committees with a tripartite structure-consisting of representatives of the state and local governments, as well as civil society-were created as deliberative institutions [23]. Because of the inherent tension in such multi-level governance regimes, conflicts emerged over values and institutional responsibilities, sometimes resulting in the need for legal intervention, with the state prosecutor's office acting as a key advocate in protecting water resources [43].

In contrast to this, in the case of Delhi, the reform of the centralized water governance structure was not based on the principles of river basin planning [44] and, instead, emerged from more short-term political exigencies. As discussed earlier, the limited accountability of urban local bodies in Delhi to local citizenry had led to growing frustration among residents about the inadequacy and unreliability of basic civic services. A government-citizen partnership program, called the Bhagidaari program, was launched as consequence in 2000. The idea was to develop a framework for partnership between citizen groups (which came to be known as Resident Welfare Associations (RWAs)) and government officials to address neighborhood level problems such as, water delivery and waste management. Unlike the reforms in MRSP at the river basin level, the focus of the Bhagidaari program was largely at the neighborhood level [45].

Moving from structure to the processes that underlie water governance in each city helps provide additional insights into the rules and functional domains that are associated with the various agencies at each level. In the case of Delhi, although the Bhagidaari program has enhanced civic participation, it lacks statutory authority and has failed to usher any transformational change beyond holding service providers accountable to some extent to the local citizenry [45]. Moreover, since there is no separate provision for funding under this program, the scope of the partnership in terms of undertaking new investments or addressing underlying conflicts is quite limited. The reforms have also done little to enhance the capacity of urban local bodies such as the DJB. Decisions such as those regarding tariff restructuring and expanding coverage to unrecognized slums and squatter settlements still cannot be taken by DJB without the approval of the state assembly and tend to be highly politicized. DJB also relies heavily on the local government for support of recurrent and capital expenditures [46], but this support has been inadequate given the growing requirements of the population.

As opposed to this, in the case of MRSP, the establishment of the main state-level utility, SABESP, as a mixed company gave it greater financial autonomy. Although the state of Sao Paulo has a majority stake, SABESP is free to raise capital in the global market. Additional financial support for achieving 
the goal to expand the scope of WSS and to promote greater interagency collaboration in recent years was enabled by federal plans such as the Growth Acceleration Program (Programa de Aceleração de Crescimento (PAC) ) [37]. The availability of this financing mechanism has also facilitated collaboration between various water management entities and other urban agencies such as the State Housing and Urban Development Company.

Our discussion in this subsection has attempted to unpack some of the complexity of water governance in metropolitan areas and to highlight the challenges of decentralization. In the case of MRSP, decentralization reforms entailed "multi-directional power transfers that reconfigured responsibilities, resources and power" among actors and institutions at various levels not only from central government to existing lower level bodies but also from state and federal agencies to new regional entities organized around hydrologic lines that overlap traditional administrative boundaries [47] (p. 602). This sometimes led to conflict, but also cleared the way for new processes to emerge. In the case of Delhi, although the scope of decentralization reform was at a much smaller scale (neighborhood level), here too, it involved creation of new participatory arenas but with limited reconfiguration of resources and power.

\subsection{Actors Subsystem}

To examine the Actors subsystem, we begin by laying out the functional domains that are critical to the WSS sector and delineate which actors in each city are designated to carry out these functions and how they are related. We then identify gaps or overlaps (if any) within these actor-function mappings in each city and discuss the implications of this actor space.

In the infrastructural reforms literature [48] and human rights literature [49], the following three functional domains have been identified to be key in the basic services sectors (which includes not only WSS but also education, health, and energy services): provision, regulation, and service delivery. Provision refers to decisions made through constitutional and/or collective choice mechanisms about the kinds of services to be provided, how these would be provided and financed, norms regarding their distribution, and standards for the quality of these services [50]. Provision in the context of WSS thus includes policy formulation, planning, and financing. Regulation is understood as the "process of interpreting and implementing laws, policies and regulations, to achieve what was intended in their formulation" [49] (p. 22). Regulation thus includes the critical function of monitoring and enforcement. Finally, service delivery refers to the operational-level actions by service providers in providing services to the recipients/clients. In Table 3, we have listed the various actors responsible for these functional domains at different levels (federal, state, and local) in Delhi and MRSP.

Table 3 shows that provisioning in each city is carried out by agencies at higher levels (generally the federal level) while service delivery is carried out by agencies at the state/municipal levels. While these functions are delegated to separate agencies, the separation of regulation from both of these is not as clear. Provisioning and regulation functions overlap in several agencies (such as, The Brazilian Institute of Environment and Renewable Natural Resources, IBAMA in MRSP and Central Groundwater Boards, CGWB in Delhi-see Table 3). More importantly, in the case of Delhi, we observe that there is no independent regulatory agency for WSS. The regulatory functions are carried out to some extent by federal-level provisioning agencies (such as CGWD or the pollution board) or by the service delivery agency itself (DJB). In the water reform literature, the absence of an independent regulatory agency has been shown to have deleterious effects on service delivery given the low transparency and accountability of state-owned public utilities [48]. In MRSP, ARSESP (São Paulo State Sanitation and Energy Regulator (Agencia Reguladora de Saneamento e Energia do Estado de São Paulo)) regulates water when it is under treatment or control by service providers and CETESB is responsible for the monitoring and licensing of activities that generate pollution. The combined efforts of CETESB and ARSESP do provide some degree of broad-based oversight as well as the ability to work with other institutions to remedy shortcomings through both formal and informal meetings, agreements, and projects. In Delhi, the need for an independent regulatory agency has been recognized by the Delhi 
Government [51], but at the time of this writing, no such agency had yet been set up. The court in Delhi, through Public Interest Litigation (PIL) cases, has on several occasions taken up this role of a regulatory agency, such as in the cases related to pollution of River Yamuna and to the lack of water and sanitation services for unauthorized colonies [52].

Another important thing to note in Table 3 is that there is no separate state-level provisioning agency in Delhi. There is an urgent need for long- and medium-term planning for Delhi's water future given the threats from urbanization, continued population growth, and climate change. In MRSP, on the other hand, there is quite a bit of overlap among agencies working within the same functional domain, which may be helpful (as it brings multiple perspectives) or may be counterproductive (if the roles are ambiguous). An illustration of the latter is provided by Reference [53] wherein the author points out that the "constitution did not specify whether state or municipal entities were responsible for sanitation"; this made SABESP hesitant to invest in infrastructure because it feared that the "municipalities might claim these systems once they had been constructed" (p. 82). In Delhi, service provision by the public utility (DJB) is highly deficient and the gap in water services is filled by numerous private providers or through self-provisioning, both of which are not regulated at all. Sewage facilities for the largest municipality (DMC) is provided by DJB, while the other two municipalities are responsible for provision of their own sewage facilities. In MRSP, water provision is largely done by SABESP and a smattering of municipal providers but there are no private providers. In sanitation, private firms have been contracted in more municipalities than in water provision, but SABESP remains by far the largest provider.

Besides these actors within the WSS sector, there are actors in related sectors/spheres that play a key role. In both cities, the courts have become increasingly involved in resolving the emerging conflicts between provision of water and in meeting other social and environmental goals, as well as in holding state and private actors accountable for meeting their obligations [53]. Service provision also often requires close collaboration with government agencies involved in related sectors such as land use, waste, housing, and health. Private actors and NGOs are directly involved in service provision in Delhi, given the deficiencies in provision by DJB. On the regulation side, nongovernmental agencies (such as citizen groups and NGOs) play an important monitoring role, particularly in Delhi, where there are no independent regulatory agencies. In both cities, international donor agencies have influenced policymaking and provided financing, particularly for sanitation.

This comparative mapping of critical functional domains to key actors and their interrelationships in a multilevel governance framework offers several takeaway points. First, our assessment shows where there are overlaps among key functions and where there are critical gaps. In the case of Delhi, we see a critical gap in provision at the state level, gaps with respect to regulation and a proliferation of service providers. On the other hand, in the case of MRSP, we see quite a bit of overlap between state and municipal level agencies working within the same functional domain, which may at times be counterproductive (as the sanitation example showed). Second, this gap assessment also helps better understand the role of "emergent actors" such as courts and citizen groups that have arisen to demand that some of the missing functional requirements be fulfilled. Finally, this actor subsystem assessment also helps highlight spaces for collaboration and conflict among actors that have emerged in the course of history. All of these observations have important implications on outcomes observed in each city, as we examine next. 
Table 3. Key actors for provision, regulation, and service provision in São Paulo and Delhi.

\begin{tabular}{|c|c|c|}
\hline Functional Domain & São Paulo & Delhi \\
\hline \multicolumn{3}{|c|}{ Federal Level } \\
\hline $\begin{array}{l}\text { Provision only Provision }+ \text { regulation } \\
\text { Advisory bodies for provision }\end{array}$ & $\begin{array}{l}\text { ANA: The National Water Agency coordinates integrated management of } \\
\text { water resources and is responsible for settling hydropower and interbasin } \\
\text { river issues. } \\
\text { IBAMA: The Brazilian Institute of Environment and Renewable Natural } \\
\text { Resources is an executive agency that develops national standards and } \\
\text { ensures that they are followed, that enforces environmental rules, and that } \\
\text { issues fines and penalties for environmental violations. } \\
\text { CNRH: National Council for Water Resources (Conselho Nacional de } \\
\text { Recursos Hídricos) advisory board for water regulations; } \\
\text { CONAMA: National Council for the Environment (Conselho Nacional do } \\
\text { Meio Ambiente) advisory board for environmental regulation. }\end{array}$ & $\begin{array}{c}\text { Ministry of Water frames national policy on water. } \\
\text { National Water Development Agency assesses interbasin transfer options } \\
\text { Central Ground Water Board (CGWB) sets policy, monitors groundwater } \\
\text { flows, and enforces withdrawal norms. } \\
\text { Central Pollution Control Board (CPCB) develops national pollution } \\
\text { standards and works as a state pollution agency for Union Territories in } \\
\text { enforcing pollution standards. } \\
\text { Central Water Commission sets policy for surface water. }\end{array}$ \\
\hline \multicolumn{3}{|c|}{ State Level } \\
\hline Provision Provision + regulation & $\begin{array}{l}\text { DAEE: Department of Water and Electrical Energy (Departamento de } \\
\text { Águas e Energia Elétrica) is the state water resources management agency } \\
\text { responsible for issuing water use permits and concessions in the São Paulo } \\
\text { State. } \\
\text { SSRH: State Sanitation and Water Resources Secretariat (Secretaria } \\
\text { Estadual de Saneamento e Recursos Hídricos) establishes state water } \\
\text { resources policy and coordinates state water management system and } \\
\text { associated agencies (incl. DAEE and SABESP) }\end{array}$ & \\
\hline Regulation only & $\begin{array}{l}\text { ARSESP: São Paulo State Sanitation and Energy Regulator (Agencia } \\
\text { Reguladora de Saneamento e Energia do Estado de São Paulo) created in } \\
2007 \text { regulates water when it is under treatment or control by SABESP, as } \\
\text { well as municipal providers. } \\
\text { CETESB: State Environment Agency (Centro Tecnológico de Saneamento } \\
\text { Básico, 1968-2009) regulates pollution and is responsible for the control, } \\
\text { inspection, monitoring, and licensing of activities that generate pollution. }\end{array}$ & \\
\hline \multicolumn{3}{|c|}{$\begin{array}{l}\text { Service Provision: State and Municipal Levels } \\
\end{array}$} \\
\hline Service providers & $\begin{array}{l}\text { State level: São Paulo State Water and Waste Company (SABESP) } \\
\text { created in } 1973 \text { is responsible for the supply and distribution of water and } \\
\text { sanitation services in MRSP and has a mixed public-private ownership, } \\
\text { with the State of SP holding a majority } 50.3 \% \text { stake. } \\
\text { Municipal level: A couple of municipalities are not supplied by SABESP } \\
\text { and have their own local urban water supply services. } \\
\text { Private providers: for sanitation }\end{array}$ & $\begin{array}{l}\text { State level: Delhi Jal Board (DJB) constituted in } 1998 \text { is responsible for the } \\
\text { supply and distribution of potable water as well as the treatment and } \\
\text { disposal of wastewater. Sewage: DJB is responsible for providing sewerage } \\
\text { facilities in one municipality (MCD). In the other two municipalities, } \\
\text { the two local bodies are responsible for providing sewerage. } \\
\text { Private providers: a number of independent providers for water } \\
\text { and sanitation }\end{array}$ \\
\hline
\end{tabular}




\subsection{Interactions, Outcomes, and Trajectory of Water Systems: Using the SES Module as an Analytical and Diagnostic Tool}

In this subsection, we discuss how the interrelationships and feedbacks among the subsystems outlined above help explain the functioning of the overall water system. In the SES framework, "interactions" refer to processes and activities-such as information sharing, deliberation, lobbying, self-organizing, and networking - that actors of different types collectively engage in to influence specific outcomes [11,12]. These interactions among different types of actors is critical because, as Evans (2002) reminds us, "focusing on one particular type of agent or actor is misleading"; instead, we need to conceptualize agents as being interconnected - an "ecology of agents", as he terms it [54] (p. 22).

Building on this conceptualization of "ecology of agents," we turn now to assessing the trajectory of the water systems in these cities in terms of three outcomes: provision of safe water, provision of sanitation services, and resilience of the system. For each of these outcomes, we explore how the urban SES module that we have developed can serve a) as an analytical tool to help us understand what motivated specific types of actors to come together, what specific strategies and agendas were framed and implemented by them, and why and b) as a diagnostic tool in a comparative setting to examine why desired outcomes in terms of service delivery and/or resilience were not achieved.

\subsubsection{Potable Water Provision: Why Has Delhi Lagged Relative to MRSP?}

The most basic outcome variable is the coverage rate of piped water services. In 1970, Delhi with $70 \%$ coverage scored better than MRSP at 63\% (Table 1). However, by 1990, the picture had reversed with MRSP at $96 \%$ and Delhi at $76 \%$ coverage. Almost universal coverage of piped water supply was achieved in MRSP by the turn of the century, although given its large population size, some estimates suggest a fairly large absolute number of unserved people (around 1.2 million in the metropolitan area in 2006) [37]. According to the latest estimates, coverage rates in Delhi are much lower, around 83\% in 2018 [36]. In this subsection, we illustrate how our SES module can be used as an analytical and diagnostic tool to shed light on some important differences in the configuration of key SES elements and their interactions that stalled progress in Delhi relative to the case of MRSP.

As we saw, in both cities, the 1960s and 70s were a period of rapid population growth; more so in MRSP than Delhi, where poor migrants settled in the peripheries and built their own houses (autoconstruction). It was the struggle for survival and the legal difficulties of autoconstruction that mobilized these peripheral settlers in MRSP to fight collectively for their rights to the city [27]. Over time, as democracy took hold through institutional and legal reforms, activists and their allies in state institutions worked increasingly together on projects addressing urban socio-environmental challenges [55]. Networking activities among actors in state agencies and activist organizations were critical in mobilizing public opinion and in framing and pushing the reform agenda. Although state water agencies had long been characterized as insular technocratic structures, the citizen movements of the 1970s and 1980s "created democratizing pressures within the technical agencies themselves" and led them to "reconstitute their roles and legitimize their activities in these new circumstances" [29] (p. 167).

It was within this changed institutional and political environment that universal coverage of piped water emerged as a politically salient goal for SABESP and that definite targets were set for achieving this goal [29]. The massive water infrastructure-in the form of dams and reservoirs-that was built earlier for meeting energy needs of the industrial sector was leveraged, together with the technical capacity that already existed within SABESP and with new sources of funding (e.g., through PAC), to take on this challenge of universal coverage. Our urban SES module, by laying out the different subsystems and their underlying variables, helps to identify the configuration of variables and their relationships at specific points in time that explain how this transition took place.

Turning now to the case of Delhi, we see a somewhat reversed movement with strong democratic fervor and relatively more pro-poor policies in 1950s, followed by a gradual movement towards a more 
hostile policy environment for the poor in subsequent decades. In the 1950s, an important legislation passed was the Slum Act of 1956, which called for "the improvement and clearance of slum areas and for the protection of tenants in such areas from eviction" [56] (p. 1.). This was followed shortly afterwards by the First Master Plan for Delhi, which came into effect in 1962, and envisaged giving plots to slum households at resettlement sites. Taken in isolation, both these actions seemed like positive steps towards sustainability. However, as we discussed earlier, effective resettlement required coordinated action by several government agencies at different levels: land (federal), slum management (state/municipal), and water (state/municipal). Due to the highly fragmented governance structure in Delhi, there were problems of coordination between these agencies, coupled with lack of local control, accountability, and capacity. This contributed to a wide divergence between well-intentioned policy statements and their implementation. A majority of households chosen for resettlement returned back to the city core, thus negating the planning efforts behind the resettlement and leading to distrust in the government.

While there was widespread support behind the slum resettlement in the 1950s in Delhi, the lack of clarity about the process, allegations of illegal land deals, and corruption charges divided public opinion and scuttled any attempts to devise consistent slum resettlement policies. With the introduction of neoliberal reform in 1990s and media campaigns around the "world class city" image of Delhi-especially after the announcement of commonwealth games in Delhi-the claims of the poor as legitimate urban citizens got further eroded and the poor came to be represented as "economically unviable, environmentally harmful and criminal" [52] (p. 141). This change in attitude towards the poor was also reflected to some extent in court judgements. A recent analysis of case law on informality in India by Reference [52] found a distinct change from the late 1970s, when Public Interest Litigation was first introduced and when several landmark judgements recognized the rights of livelihood of the poor, to the 1990s, when neoliberal reforms were introduced and when there was a significant increase in the number of evictions. The possibilities for democratization that had opened up in the 1950s dissipated within this fragmented landscape and were never translated into the kind of citywide movements for basic services that pressured the state to respond in MRSP. As the city continued to be flooded with poor migrants, especially fueled by the demand generated by the construction boom in 1990s and 2000s, informal settlements with varied degrees of illegality multiplied. Their demands for basic service provision were channeled through enlisting the support of local politicians via patron-client relationships rather than through broader legislative change. This resulted in an ad hoc process of regularization of slums and made it very challenging for the public utility to effectively budget and plan for service provision [51]. Gaps in service provision were largely filled by private water vendors who charged high prices from the poor population unserved by the public utility. Unlike the case of MRSP, where the peripheralization of the poor contributed to their mobilization for basic rights, slum households in Delhi are peppered all across the metropolitan area and do not show a strong spatial concentration, which hinders collective action.

The above description, although somewhat simplistic, provides a helpful illustration of the various enabling factors (derived from our SES module) that together explain how the transformation from poor coverage to almost universal coverage for water has been achieved to a large extent in MRSP but not yet in Delhi. The narrative here confirms the proposition that it is neither the state nor civil society but the continuing interaction between committed individuals in both that provides the strongest possibilities for transformation [54]. The comparative analysis above also points to the critical role of timing of specific events in the transition process (Table 2). Critical windows of opportunity may open up at certain times (such as immediately following independence in Delhi in the 1950s and after the transition to democracy in MRSP in the late 1980s) when networks of key actors need to be ready to mobilize, supported by enabling legislation and funding mechanisms. Although MRSP's progress as measured by indicators of piped water coverage is impressive, we need to be cautious that the transformation to sustainability involves much more than just this single indicator. Beyond water 
coverage, there still remain some significant challenges related to sanitation coverage, water quality, and long-term sustainability of supply that we discuss next.

3.7.2. Provision of Sanitation Services and Governance of Water Quality: Why Has Progress Been So Slow in Both Cities?

Strategies for water sustainability should ideally embody the integrative ecological principles of the underlying water cycle; this calls for close coordination among the different agencies responsible for water as it moves along this cycle. However, in both cities, at least up to the 1990s, separate agencies managed water supply and sanitation and there were no mechanisms for coordination with other agencies whose activities affected water supply and quality (such as housing, health, industry, and agriculture) $[29,40]$. In the case of Brazil, sanitation was not even considered part of water resource management up until the 1990s [29].

An important reason that improving sanitation coverage is more difficult than improving piped water coverage is that residents seem less willing to pay for sewage disposal and treatment, which is "out of sight, out of mind" than the clearly visible pipes that bring much needed water to their homes [53]. Provision of sanitation infrastructure has not historically had the same political salience as provision of piped water supply, either among citizen groups or the providers of such services. Thus, it is not surprising that, until the 1990s, there were few specialized funds or earmarked public resources to support the large infrastructure investments required to meet the demand for wastewater collection and treatment in both cities [57]. The need for sanitation infrastructure was most acute in informal settlements in environmentally protected areas, but until the early 1990s, water service providers in both cities did not have the mandate to invest in sanitation infrastructure.

Despite these challenges, there were significant advances in sanitation provision in MRSP in the decades of 1990s and 2000s, but progress has been much slower in Delhi. In MRSP, the recognition of citizens' entitlement to the urban space and basic urban services that followed the democratization movements in the 1980s did not directly lead to significant expansion in sanitation provision (unlike the case of piped water provision) but it did lay the groundwork for broader legislative changes that also impacted sanitation conditions [29]. Thus, for instance, the new water resource management law passed in 1991 provided for multiple uses of water resources, decentralized water resource management, and encouraged participation by users and citizens' groups in management decisions [30]. Another significant piece of legislation, passed at the end of 1997, was designed to protect water catchment areas. These legislations drew heavily on a prior process of public hearings and debates involving both state representatives and organizations of civil society. Moving away from a system of rigid zoning, the new legislations supported the engagement of municipalities and civil society organizations through the creation of watershed committees, which were tasked with looking into the specificities of each watershed to resolve conflicts of interest [28].

The democratization movements also succeeded in creating a network of committed actors who, in their subsequent placements in varied state and non-state organizations, continued to coordinate their efforts towards developing an integrated vision of the water system. These actors worked together, combining their technical expertise with their ties to the community while also leveraging their connections to media and to legal actors, in order to increase awareness about the urgency of water-quality issues and its links to aquatic and human health [29]. Several municipalities in the region drafted new municipal zoning and development plans, as they "sought a pragmatic approach to development in the protected areas, calling for relaxation of the existing legal strictures in order to leave current occupants where they were, construct adequate sanitation infrastructure, and institute monitoring and controls to prevent further growth" [29] (p. 185). This was complemented at the federal level by the Basic Sanitation Law of 2007, which is an example of another strong legislation that provides a comprehensive definition of the term "sanitation," mandates standards for it, and provides for financial and institutional mechanisms [58]. From 2007 to 2014, the sector received over 
USD 17 billion mainly via PAC (Programme for Accelerated Growth) and significant investments in sanitation coverage were made [58].

Together with this growing awareness about sanitation issues, coupled with legislative changes, the courts played an influential role in holding the state accountable. This is evident in a number of court cases, notably a relatively recent ruling by a regional appeals court that municipalities can be prosecuted for failing to provide sanitation [53]. As the public prosecutor's office and the courts began to pressure SABESP and municipalities to install sanitation infrastructure [59], there was significant expansion in coverage, but the process is far from complete. As of $2017,10 \%$ of sewage in São Paulo state was still not collected and $25 \%$ of households were not connected to sewage treatment plants [60].

In contrast to this, in the case of Delhi, the proportion of households not connected to sewage treatment plants is much higher at $45 \%$, according to the latest estimates [61]. Here too, the initial impetus for the construction of sewage infrastructure was largely provided by a landmark case in the Supreme Court (Mailee Yamuna: Writ Petition (Civil) No.725/1994) in 1994. This case is particularly interesting because the Supreme Court on its own took cognizance of a news item on pollution of the River Yamuna and issued notices in 1996 to the Central Pollution Control Board (CPCB) to conduct environmental impact studies. Based on its assessment, $\mathrm{CPCB}$ recommended that adequate sewer lines and sewage treatment plants should be set up and that untreated sewage should not be allowed to flow into the storm water drains [40]. Although these recommendations reflect an integrated vision of water management, implementation was fragmented and disconnected. Delhi Pollution Control Committee (DPCC) informed the courts that it would set up 16 sewage treatment plants and make them operational by 1997. However, by the year 2000, only eight of these were under construction, with the result that growth in sewage treatment capacity did not keep pace with the increase in population and waste. The city's treatment capacity increased seven fold over the period 1960-2008, but this investment was thwarted by a 12-fold increase in wastewater generation due to an increase in population over the same period [40]. Ironically, of the limited sewage treatment capacity that was set up, only around $66 \%$ was actually used in 2005 [40] because complementary investments in setting up sewer lines and connecting them to sewer treatment plants were not undertaken.

There are other problems too in Delhi, which demonstrate why making progress in sanitation provision requires coordinated effort by several state and non-state actors, coupled with legal and institutional reform, consistent planning, and significant funding commitment to make it all come together. The fundamental problem in Delhi has been that of sewage not reaching the treatment plants. This happens either because sewage lines exist but do not function well because of lack of maintenance or because sewage lines do not exist (this is the case for almost half of Delhi's population living in unauthorized or illegal colonies) [40]. The Delhi government does not have any concrete plans for setting up sewage systems in densely inhabited and illegal settlements [40]. Its official stance has been that sewage facilities are not being provided because of narrow lanes in the clusters and because the clusters get relocated from time to time [40]. Besides this technological constraint, there are also serious funding constraints. A recent analysis of budget and tracking of public expenditures of Delhi Government found spending on water and sanitation services (WSS) to be woefully inadequate given the development realities of this rapidly growing megacity [62]. In 2011-12, the budget for WSS constituted just around $0.5 \%$ of the gross state domestic product of Delhi, although WSS was often claimed to be one of the priority areas of the government [62].

In both cities, although courts played a critical role in pushing the sanitation agenda forward, our comparative analysis in this subsection points to the critical role of complementary reforms and actions needed to address the complex challenges in the sanitation sector. In the case of MRSP, the legislative reforms (e.g., Basic Sanitation Law of 2007) and institutional changes (e.g., formation of River Basin committees) that accompanied the court directives helped address some of the challenges (such as barriers to expansion in informal settlements and improvements in transparency and accountability) and pressured service providers to make universal coverage part of their mandate. Complementary investments made in regularization of favelas and increased funding received through special initiatives 
(e.g., PAC) further enabled the implementation of the courts' directives. Finally, recognition of citizens' entitlement to the urban space premised on the idea of "Right to City" provided the necessary language and participative space for community activities and their allies to coordinate their efforts towards realizing a more integrative vision of water-system reform in MRSP [63]. However, as one of the interviewers in MRSP cautioned, "it is important to note that many social movements were absorbed into privately funded work and otherwise disarticulated in recent years" [64], which may account for why progress has been slower of late. In contrast to this, in the case of Delhi, although there was strong judicial activism, it did not lead to any major legislative and institutional changes and enforcement of court directives was weak. This reflects critical missing links (e.g., between judges, bureaucrats, and activists) in the ecology of actors in Delhi.

Beyond meeting current needs for basic service provision, an important goal of sustainable water governance is about meeting future needs and building resilience in the face of climate uncertainties. In the next subsection, we discuss how the two cities fare in this respect.

\subsubsection{Resilience in Face of Climate Uncertainties: A Continuing Challenge}

Although the record of MRSP in expanding coverage of water and sanitation services is impressive, it still remains highly vulnerable to climate change. In 2014-15, Sao Paulo witnessed one of the worst water crises in the region's historical records. It resulted from a number of interlinked factors. The first driving factor was the lower-than-average precipitation during the summer months of January-March 2014 when temperatures also soared, leading to higher consumption of water as well as hydroelectricity [65] . By February 2015, the total water volume in the MRSP reservoirs was at 22 percent of its capacity. The second important reason was the continuously growing demand for water from the city of more than 20 million, which has strained particularly the Cantareira system that provides almost half of the city's water. For nearly 15 of the 17 years between 1997 and 2013, the annual inflows to the Cantareira system were below the long-term average. Despite these pressures on the system, in 2002, special contracts known as "guaranteed demand contracts" were instituted for commercial and industrial clients [65]. Under such agreements, consumers were offered discounts (up to $75 \%$ ) for a fixed quantity of water at a fixed price, an arrangement that several researchers argue "encourages irrational water use" [65] (p. 11). Finally, despite legislation, no contingency plans were drawn up before the time of crisis [65]. By 2016, the only plans that were announced were related to investments to augment the supply of water. Despite the strain that consumption places on the system, attempts to control demand or to increase efficiency in MRSP have been very limited, in part because convincing consumers and producers to live with scarcity in a semitropical region is both difficult and politically unappealing. Consequently, the emphasis has been on constantly increasing supply, a strategy that is quickly coming up against both administrative and ecological limits. Beyond these proximate causes for the crisis, the origins of the crisis have been traced to more distant places and events, such as trends in precipitation received linked to the condition of the Amazon forest, as mentioned above.

Responses to the emerging drought situation were mostly short term in nature, with SABESP interrupting supply either through closing valves or by reducing pressure. The fact that these operations were largely initiated in peripheral neighborhoods with no prior communication to consumers [65] raised questions of injustice and inclusion. The official line was to continue to deny "cuts" were taking place, despite evidence to the contrary [65]. Although a crisis committee was established, there was no public explanation provided for the criteria used for their selection [28].

This discussion on the recent drought in MRSP shows that, beyond the progress made in MRSP in terms of current indicators of water and sanitation provision, there are very serious issues related to ensuring provision of these basic services in the future. In terms of the urban SES module outlined in the previous section, the source of future vulnerabilities lies in the interactions between the demands of a large population residing within a very small area due to its promise of economic opportunities (demographic and economic setting); a long legacy of centralized control, which despite decentralization 
reforms, has been hard to breach (political setting); socio-spatial differentiation of living conditions with hot spots of vulnerability concentrated in the peripheries (settlement subsystem); an extensive system of water infrastructure, which is highly dependent on interbasin transfers and, thus, potent ground for political conflicts; and a complex multilevel water governance structure that has undergone a series of reforms to be more responsive to societal needs and environmental change but is ill-equipped to deal with future climate uncertainties.

In the case of Delhi, water supply deficit has been a continuing problem, which continues to date and is expected to intensify in the future. In order to meet the large deficit in its water supply, the city has invested in several large-scale projects that include construction of dams across the tributaries of the River Yamuna [40] However, construction of dams—specifically Renuka dam, which is about $100 \mathrm{~km}$ from Delhi-has come under a lot of controversy and has brought to the surface underlying tensions between rural versus urban, agricultural versus industrial/municipal, and human versus environmental uses of water. Groundwater is becoming increasingly important as an alternate source of supply, and unregulated investments in groundwater have emerged as a major concern. It is estimated that, over the past decade, the groundwater table has fallen by about a meter in most places, with some areas in south and southwestern parts of the city reporting a decline of 2-3 meters [65]. In MRSP also, groundwater tables are reported to be falling, although in this case, it is mostly due to industrial uses since SABESP meets most of the domestic water requirements through surface water sources (SABESP, 2008).

In the next section, we expand the discussion beyond these cities to bring in examples and cross-learnings from other cities. These cross-learnings illustrate the use of our module as a prescriptive tool to move towards more holistic solutions in the future, not in the sense of prescribing specific solutions from the outside, but by showing how probing underlying systemic factors can reveal pathways for the future.

\section{Discussion: Use of Urban Water SES Module as a Prescriptive Tool Based on Cross-Learnings}

It is interesting to note that several of the sustainability challenges we have discussed for our two study cities are shared more broadly across cities in the global south. These include vulnerabilities from climate change, degraded waterways, groundwater depletion, resource and capacity constraints, and inequities in access. The water crisis in Chennai, India's sixth largest city, is a good example. At the height of the crisis, the city had to resort to transporting water through special purpose trains from largely rural sources hundreds of miles away [4]. Clearly, these kinds of band-aid solutions are unsustainable and there is need for wider public discussion on the systemic causes of the crisis. This is where our SES module can be helpful as a diagnostic tool: to reveal the key socio-ecological factors and their interrelationships that lead to such a situation. Although the proximate cause of the crisis was weak monsoons, which led the city's four main reservoirs to dry up in summer 2019, several researchers have argued that the problem runs deeper and that its causes lie in years of mismanagement of water resources and unplanned urbanization [4]. Just as we saw in the case of our study cities, due to the lack of affordable housing and poor enforcement of existing laws (e.g., protection of critical watersheds), there has been rapid growth of various kinds of informal settlements, which has far outpaced the capacity of water agencies to provide service. This capacity is further challenged by the siloed structure within which different agencies operate, with limited coordination among agencies that manage water provision and those that manage sewage and land use, and limited spaces for participation by citizens and social learning. Some of these problems, such as strong legacy of centralized control, and lack of participation and social learning were also revealed in the crisis of MRSP (as we explained earlier) as well as in Cape Town [2]. Additionally, in both these cases, water conservation measures which had long been proposed were implemented too late and only partially after the crisis hit [2,61].

In all these cases, the crises revealed the deep inequities in water access, with poor residents of informal settlements being most vulnerable. Rather than the narrow approach of just looking for more distant water sources to meet ever increasing water demand, managing the water cycle in an integrated 
manner can help reveal a broader set of solution pathways, such as through rainwater harvesting, wastewater reuse, and increasing sewage treatment capacity. All of these solution options have been proposed for Chennai [1]. However, as our discussion of transition processes in MRSP and Delhi using the SES module has shown, realization of change on the ground will require mutually reinforcing changes in water infrastructure, institutions, and actor networks in order to move entrenched systems into new directions.

Challenges related to urban water sustainability are not limited to cities in the global south. Several new theories, visions, and solutions have entered the discourse on urban sustainability from cities in the global north. A common thread underlying this discourse is the recognition of growing uncertainties and variability in water systems, calling for the need for adaptive management and social learning [66]. The emerging water sustainability paradigm encapsulates the idea of integrated management of the water cycle to protect the health of the watersheds from which water is sourced, to mitigate flood risks, to focus on green infrastructure, and to create public spaces that deliver multiple ecosystem services through reuse and recycling of water [67]. Several solutions have been proposed that build on this idea of green infrastructure and water-based ecosystem services. In Delhi, this includes the use of floodplains of the River Yamuna to store large quantities of water [68]. To increase groundwater recharge, it is proposed that several barrages with embankments be built from the entry point of the river into the city to its exit point. It is estimated that these floodplains could yield around 700 cubic meters of water on average annually, which is around $68 \%$ of the water annually supplied by Delhi Jal Board [68]. However, as our module reveals, there are important hurdles, including dealing with the unregulated encroachments on floodplains and contamination of the flood plains through sewage drains and other wastes. Despite these problems, this is an innovative solution which could yield other associated ecological services (like biodiversity). However, its financial and human costs-in terms of the displacement of current residents and their sources of livelihoods-is yet another example of the emerging conflicts among human and ecological needs. Such ecosystem service-based solutions have been proposed and implemented to some extent in the MRSP, as well. Studies led by The Nature Conservancy suggests that re-establishing the riparian vegetation along the rivers that supply the Cantareira system would cost much less than the billions to be spent on civil engineering works announced by the state government in response to the water crisis [69]. This type of solution has the potential to minimize the risk of extreme events and to reduce the vulnerability of populations to floods and prolonged droughts. However, its design and implementation require careful attention towards not only the ecological and technological dimensions but also the interrelated social and political aspects of negotiating such a change, as our module suggests.

\section{Conclusions}

In this paper, we developed and applied the urban water SES module as a tool to untangle the complexity of urban water systems by identifying, categorizing, and organizing variables and processes for comparative analysis of water systems in megacities. A distinct advantage of this systems-based tool is that it helps in identifying the interconnections among social and ecological factors and processes that are generally missed in sector-specific or disciplinary approaches to water management. We also showed how this tool can be used both as an analytical and as a diagnostic tool to enable a structured process of context-specific inquiry to identify and evaluate what critical factors might be missing or undeveloped in any problem setting and to use this understanding as the basis for exploring holistic solutions.

On the analytical side, a specific contribution of our module is the conceptualization of "settlements" as one of the core subsystems, which is critical to understanding urban SESs, as opposed to the more widely studied cases of SESs in rural contexts. During the process of urbanization, a wide diversity of settlements emerge, and access to public services is often closely linked with the type of settlement (as defined by the history of settlement, degree of legality, type of housing, demographic characteristics, and population density). While this emergence of diversity in settlement types and its linkage to access 
to public services is observed broadly across cities around the globe, this phenomenon is particularly salient in cities of the global south where rapid urbanization has happened largely in the absence of systematic planning and regulation. In order to advance urban sustainability in these contexts, our work underscores the need for understanding this diversity of settlements and its sustainability implications through characterizing "settlements" as a subsystem within the SES framework and through examining its coupling with other subsystems, such as water infrastructure and water governance subsystems. By highlighting these couplings, our module has helped us to better understand the challenges of achieving universal coverage not only in terms of expanding physical infrastructure but also in terms of the more difficult challenge of addressing the rather messy governance issues entailed in expanding coverage to settlements with varied (and often unclear) legal status.

On the diagnostic side, using this module has enabled us to probe deeper into the configuration of variables and processes that facilitate (or hinder) the attainment of desired goals. For example, our analysis showed how mobilization of citizen groups following the democracy movements in MRSP in the late 1980s and the networking of these groups with key actors in different state agencies was critical in pushing through a series of governance reforms, which eventually paved the path towards universal provision of potable water in MRSP. However, it is interesting to note that for sanitation - the benefits of which are relatively less visible and tangible-the mechanism for change was not really through citizen mobilization and networking. Here, the courts played a major role in both cities in terms of pressuring the state to take action against the unsustainable levels of water pollution in rivers due to the flow of untreated sewage. Bringing about effective change in sanitation also required complementary investments and actions by several different state and non-state actors. This coordination was particularly challenging to achieve in Delhi because of its highly fragmented governance structure, lack of adequate funding, and missing links in the ecology of actors. Building on this diagnosis and a broader discussion around cases of similar cities in the global south, we also explored possible pathways for sustainability through, for instance, investing in green infrastructure and building capacity for adaptive co-management.

We acknowledge that our module is in its early stages of development and would need to be refined through varied applications to fully realize its potential as a diagnostic and prescriptive tool. Our long-term research agenda is to apply this module to a range of cities to understand (a) challenges that arise at the urban scale due to the complexity of interactions between human needs and ecological limits and (b) adaptive responses that emerge (or fail to emerge). In this endeavor, we are inspired by Ostrom's observation that "without the capacity to undertake systematic, comparative institutional assessments, recommendations of reform may be based on naive ideas about which kinds of institutions are "good" or "bad" ... . One needs a common framework and family of theories in order to address questions of reform and transition." [70] (p. 9). We hope that this module will provide a basis for carrying out more extensive comparative studies and will help cumulate knowledge from other cities to provide further insights on how to address the multilevel and cross-scalar challenges of urban water management.

Author Contributions: Conceptualization, R.M.A. and L.H.; Methodology, R.M.A.; Formal Analysis, R.M.A. and L.H.; Resources, R.M.A. and L.H.; Data Curation, R.M.A. and L.H.; Writing-Original Draft Preparation, R.M.A.; Writing-Review and Editing, L.H. and R.M.A.; Project Administration, L.H.; Funding Acquisition, R.M.A. and L.H.

Funding: This research was funded by the National Science Foundation under Grant Number SES-LSS 1324248 and by Fulbright grants received by the first author to India and by the second author to Brazil. Any opinions, findings, conclusions, or recommendations expressed in this material are those of the authors and do not necessarily reflect the views of the National Science Foundation or the Fulbright Commission.

Conflicts of Interest: The authors declare no conflict of interest. The funders had no role in the design of the study; in the collection, analyses, or interpretation of data; in the writing of the manuscript; or in the decision to publish the results. 


\section{References}

1. Palanichamy, R.B. How Does a Flood-prone City Run Out of Water? Inside Chennai's “Day Zero" Crisis. In Does Flood-Prone City Run Water Chennai's "Day Zero" Crisis; World Resource Institute: Washington, DC, USA, 2019. Available online: https://www.wri.org/blog/2019/06/how-does-flood-prone-city-run-out-waterinside-chennai-day-zero-crisis (accessed on 10 August 2019).

2. Alexander, C. Cape Town's 'Day Zero' Water Crisis, One Year Later; City Lab/The Atlantic: Washington, DC, USA, 2019. Available online: https://www.citylab.com/environment/2019/04/cape-town-water-conservationsouth-africa-drought/587011/ (accessed on 10 August 2019).

3. Milly, P.C.D.; Betancourt, J.; Falkenmark, M.; Hirsch, R.M.; Kundzewicz, Z.W.; Lettenmaier, D.P.; Stouffer, R.J. Stationarity Is Dead: Whither Water Management? Science 2008, 319, 573-574. [CrossRef] [PubMed]

4. Lakshmi, K. Chennai's Day Zero: It's not just meteorology but mismanagement that's made the city run dry, 2019. The Hindu. Available online: https://www.thehindu.com/sci-tech/energy-and-environment/chennaisday-zero-its-not-just-meteorology-but-mismanagement-thats-made-the-city-run-dry/article28197491.ece (accessed on 10 August 2019).

5. McDonald, R.I.; Douglas, I.; Revenga, C.; Hale, R.; Grimm, N.; Grönwall, J.; Fekete, B. Global Urban Growth and the Geography of Water Availability, Quality, and Delivery. Ambio 2011, 40, 437-446. [CrossRef] [PubMed]

6. Postel, S.L. Entering an era of water scarcity: The challenges ahead. Ecol. Appl. 2000, 10, 941-948. [CrossRef]

7. Nagendra, H.; Bai, X.; Brondizio, E.S.; Lwasa, S. The urban south and the predicament of global sustainability. Nat. Sustain. 2018, 1, 341-349. [CrossRef]

8. Pelling, M.; Blackburn, S. (Eds.) Megacities and the Coast: Risk, Resilience, and Transformation; Routledge/Taylor \& Francis Group: London, UK; New York, NY, USA, 2013; ISBN 978-0-415-81504-8.

9. Satterthwaite, D.; Archer, D.; Colenbrander, S.; Dodman, D.; Hardoy, J.; Patel, S. Responding to climate change in cities and in their informal settlements and economies. In Proceedings of the Paper Prepared for the International Scientific Conference on Cities and Climate Change, Edmonton, AB, Canada, 5-7 March 2018.

10. Parnell, S.; Walawege, R. Sub-Saharan African urbanisation and global environmental change. Glob. Environ. Chang. 2011, 21, S12-S20. [CrossRef]

11. McFadden, L.; Schernewski, G. Critical reflections on a systems approach application in practice: A Baltic lagoon case study. Reg. Environ. Chang. 2014, 14, 2115-2126. [CrossRef]

12. Ostrom, E. A diagnostic approach for going beyond panaceas. Proc. Natl. Acad. Sci. USA 2007, 104, 15181-15187. [CrossRef]

13. Ostrom, E. A General Framework for Analyzing Sustainability of Social-Ecological Systems. Science 2009, 325, 419-422. [CrossRef]

14. Cole, D.H.; Epstein, G.; McGinnis, M.D. The Utility of Combining the IAD and SES Frameworks. Int. J. Commons 2019, 13, 244. [CrossRef]

15. Dubois, A.; Gadde, L.E. "Systematic combining"-A decade later. J. Bus. Res. 2014, 67, 1277-1284. [CrossRef]

16. Baldwin, C.Y.; Clark, K.B. Design Rules; MIT Press: Cambridge, MA, USA, 2000; ISBN 978-0-262-02466-2.

17. Cox, M. Understanding large social-ecological systems: Introducing the SESMAD project. Int. J. Commons 2014, 8, 265. [CrossRef]

18. Dupont, V. Socio-spatial differentiation and residential segregation in Delhi: A question of scale? Geoforum 2004, 35, 157-175. [CrossRef]

19. Aggarwal, R.; Haglund, L. Deepening our understanding of rights realization through disaggregation and mapping: Integrating census data and participatory GIS. In Closing the Rights Gap: From Human Rights to Social Transformation; Haglund, L., Stryker, R., Eds.; University of California Press: Oakland, CA, USA, 2015; ISBN 978-0520283091.

20. Kumar, A.S.; Chandra, R.; Banerjee, R. (Eds.) Delhi Human Development Report 2006: Partnerships for Progress; Oxford University Press: New Delhi, India; New York, NY, USA, 2006; ISBN 978-0-19-568362-2.

21. Santos, M. São Paulo: A growth process full of contradictions. In The Mega-City in Latin America; Gilbert, A., Ed.; United Nations University Press: Tokyo, Japan, 1996. 
22. Bagchi, S. Governance in Delhi: Too many cooks. Econ. Polit. Wkly. 2003, 38, 4831-4832.

23. De Oliveira Campos, V.N.; Fracalanza, A.P. Governança das águas no Brasil: Conflitos pela apropriação da água e a busca da integração como consenso. Ambiente Soc. 2010, 13, 365-382. [CrossRef]

24. Ramos, L. Rain Dance: The water shortage alarming Brazil is closely related to its forests. FAFESP. Issue \# 226. 2014. Available online: https://revistapesquisa.fapesp.br/en/2014/12/26/rain-dance/ (accessed on 20 September 2019).

25. Makarieva, A.M.; Gorshkov, V.G. Biotic pump of atmospheric moisture as driver of the hydrological cycle on land. Hydrol. Earth Syst. Sci. Discuss. 2006, 3, 2621-2673. [CrossRef]

26. Nobre, A.D. The Future Climate of Amazonia, Scientific Assessment Report. Available online: http: //www.ccst.inpe.br/wp-content/uploads/2014/11/The_Future_Climate_of_Amazonia_Report.pdf (accessed on 30 July 2019).

27. Holston, J. Insurgent Citizenship: Disjunctions of Democracy and Modernity in Brazil; Information Series; Princeton Univ. Press: Princeton, NJ, USA, 2008; ISBN 978-0-691-14290-6.

28. Jacobi, P. The challenges of multi-stakeholder management in the watersheds of São Paulo. Environ. Urban. 2004, 16, 199-212. [CrossRef]

29. Keck, M. Water, Water, Everywhere, Nor Any Drop to Drink: Land Use and Water Policy in São Paulo, Brazil. In Livable Cities: Urban Struggles for Livelihood and Sustainability; Evans, P.B., Ed.; University of California Press: Berkeley, CA, USA, 2002.

30. Formiga-Johnson, R.; Kemper, K. Institutional and Policy Analysis of Decentralization on Water Resources Management in Ceaŕá State. 2005. Available online: http://papers.ssrn.com/sol3/papers.cfm?abstract_id= 757424 (accessed on 10 July 2011).

31. Kundu, A. Provision of tenurial security for the urban poor in Delhi: Recent trends and future perspectives. Habitat Int. 2004, 28, 259-274. [CrossRef]

32. Institute of Human Development. Delhi Human Development Report, 2013: Improving Lives, Promoting Inclusion; Institute for Human Development (New Delhi, India), Ed.; Academic Foundation and Institute for Human Development: New Delhi, India, 2013; ISBN 978-93-327-0086-4.

33. Haglund, L. New Forms of Environmental Governance in São Paulo: Implications for Human Rights. Lat. Am. Perspect. 2016, 43, 116-134. [CrossRef]

34. Roy, A. Urban Informality: Toward an Epistemology of Planning. J. Am. Plan. Assoc. 2005, 71, 147-158. [CrossRef]

35. Centre for Science and Environment. Excreta Matters (71 Cities: A Survey); Centre for Science and Environment: New Delhi, India, 2012; ISBN 978-81-86906-56-9.

36. Government of National Capital Territory of Delhi (GNCTD). Economic Survey of Delhi, 2008-2009; GNCTD: New Delhi, India, 2009. Available online: http://delhiplanning.nic.in/content/economic-survey-delhi-2018-19 (accessed on 22 September 2019).

37. Whately, M.; Diniz, L. São Paulo Metropolitan Water and Sewage Situation; Instituto Socioambiental: São Paulo, Brazil, 2009.

38. Ferrara, L.N. Urbanização de assentamentos precários em área de mananciais: Um balanço da atuação do poder público e os desafios que permanecem na região metropolitana de São Paulo | Slum upgrading in water source regions: A critical review of the public power performance and challenges that remain in the metropolitan area of São Paulo. Oculum Ens. 2018, 15, 413.

39. Fundação Universidade de São Paulo (FUSP). Plano da Bacia do Alto Tietê, Final Report; Fundação Universidade de São Paulo (FUSP): São Paulo, Brazil, 2008.

40. Narain, S.; Pandey, P.; Narain, S. How Urban India Is Soaking up Water, Polluting Rivers and Drowning in its Own Taste; Excreta Matters; Centre for Science and Environment: New Delhi, India, 2012; ISBN 978-81-86906-55-2.

41. Braga, B.P.F.; Porto, M.F.A.; Silva, R.T. Water Management in Metropolitan São Paulo. Int. J. Water Resour. Dev. 2006, 22, 337-352. [CrossRef]

42. SABESP. Contribuição à Nota Técnica Final ARSESP: Primeira Revisão Tarifária da SABESP; Companhia de Saneamento Básico do Estado de São Paulo (SABESP): São Paulo, Brazil, 2014.

43. McAllister, L.K. Making Law Matter: Environmental Protection and Legal Institutions in Brazil; Stanford Law Books: Stanford, CA, USA, 2008. 
44. Tiwari, P.; Chaube, R. Issues in Integrated Water Resource Management in India. J. Indian Water Resour. Soc. 2015, 35, 16-21.

45. Aggarwal, R. Reexamining the Capacity of Cities as Agents of Global Environmental Change: The Case of Delhi. Urban. Glob. Environ. Chang. Viewp. 2009, 2, 6-9.

46. Zehrah, M. Household Strategies for Coping with Unreliable Water Supplies: The Case of Delhi. Habitat Int. 2000, 24, 295-307. [CrossRef]

47. Abers, R.N.; Keck, M.E. Muddy Waters: The Political Construction of Deliberative River Basin Governance in Brazil. Int. J. Urban Reg. Res. 2006, 30, 601-622. [CrossRef]

48. Rouse, M. Institutional Governance and Regulation of Water Services: The Essential Elements, 2nd ed.; IWA Publ: London, UK, 2013; ISBN 978-1-78040-450-9.

49. Gauri, V.; Brinks, D. troduction: The Elements of Legalization and the Triangular Shape of Social and Economic Rights. In Courting Social Justice: Judicial Enforcement of Social and Economic Rights in the Developing World; Gauri, V., Brinks, D.M., Eds.; Cambridge University Press: Cambridge, UK, 2008; ISBN 978-0-511-51124-0.

50. Ostrom, E.; Schroeder, L.D.; Wynne, S.G. Institutional Incentives and Sustainable Development: Infrastructure Policies in Perspective; Theoretical Lenses on Public Policy; Westview Press: Boulder, CO, USA, 1993; ISBN 978-0-8133-1618-5.

51. DJB officials in Delhi. Personal Interview with the First Author, New Delhi, India, 2015.

52. Bhan, G. "This is no longer the city I once knew". Evictions, the urban poor and the right to the city in millennial Delhi. Environ. Urban. 2009, 21, 127-142. [CrossRef]

53. Haglund, L. Water governance and social justice in São Paulo, Brazil. Water Policy 2014, 16, 78-96. [CrossRef]

54. Evans, P.B. Introduction: Looking for Agents of Urban Livability in a Globalized Political Economy. In Livable Cities? Urban Struggles for Livelihood and Sustainability; Evans, P.B., Ed.; University of California Press: Berkeley, CA, USA, 2002; ISBN 978-0-520-23024-8.

55. Hochstetler, K.; Keck, M.E. Greening Brazil: Environmental Activism in State and Society; Duke University Press: Durham, UK, 2007; ISBN 978-0-8223-4048-5.

56. Government of India. Slum Areas (Improvement and Clearance) Act, 1956; Government of India: Delhi, India, 1956.

57. SABESP managers and technicians. Personal Interview with the Second Author, São Paulo, Brazil, 2009.

58. Chikersal, A.; Bhol, A. Urban Sanitation in India-Why Brazil Matters; Centre for Policy Research: New Delhi, India, 2018.

59. Santoro, P.F.; Ferrara, L.N.; Whately, M. Mananciais: Diagnóstico e Políticas Habitacionais; Insituto Socioambiental: São Paulo, Brazil, 2018.

60. World Bank. SABESP_Improving Water Service Access and Security in the Metropolitan Region of São Paulo Project; World Bank: Washington, DC, USA, 2018.

61. Rohilla, S.K.; Luthra, B.; Padhi, S.K.; Yadav, A.; Watwani, J.; Varma, R.S. Urban Shit: Where Does it All Go? In Down to Earth; Center for Science and Environment: New Delhi, India, 2016; Available online: https://www.downtoearth.org.in/coverage/waste/urban-shit-53422 (accessed on 8 August 2019).

62. Panda, G.R.; Agarwala, T. Public provisioning in water and sanitation: Study of urban slums in Delhi. Econ. Polit. Wkly. 2013, 48, 24-28.

63. Cymblista, R. The Challenges of the Democratic Management in Brazil: The Right to the City; Instituto Pólis: São Paulo, Brazil; Fundação Ford: New York, NY, USA, 2008.

64. Activist. National Forum for Urban Reform (Fórum Nacional de Reforma Urbana, FNRU). Personal Interview with the Second Author, São Paulo, Brazil, 2012.

65. Martins, E.; Alves, F.; Poco, R.; Amaral, R. Water Crisis and Human Rights-Report on Human Rights Violations in Water Management in the State of São Paulo; Aliança pela Água (Alliance for Water): São Paulo, Brazil, 2015.

66. Pahl-Wostl, C. A conceptual framework for analysing adaptive capacity and multi-level learning processes in resource governance regimes. Glob. Environ. Chang. 2009, 19, 354-365. [CrossRef]

67. Brown, R.R.; Rogers, B.C.; Werbeloff, L. A Framework to Guide Transitions to Water Sensitive Cities. In Urban Sustainability Transitions; Moore, T., de Haan, F., Horne, R., Gleeson, B.J., Eds.; Springer: Singapore, 2018; pp. 129-148. ISBN 978-981-10-4791-6.

68. Soni, V. Water and Carrying Capacity of a City: Delhi. Econ. Polit. Wkly. India 2003, 38, 4745-4749. 
69. Guimaraes, J.; Tiepolo, G.; Barreto, S. Ecosystem Services Modelling as a key input for decision making in the Water for São Paulo Movement; The Natural Capital Project, Stanford University: Stanford, CA, USA, 2017.

70. Ostrom, E. Background on the Institutional Analysis and Development Framework. Policy Stud. J. 2011, 1, 7-27. [CrossRef] 